\title{
Zirconium and Hafnium
}

Chapter V of

Critical Mineral Resources of the United States-Economic and Environmental Geology and Prospects for Future Supply
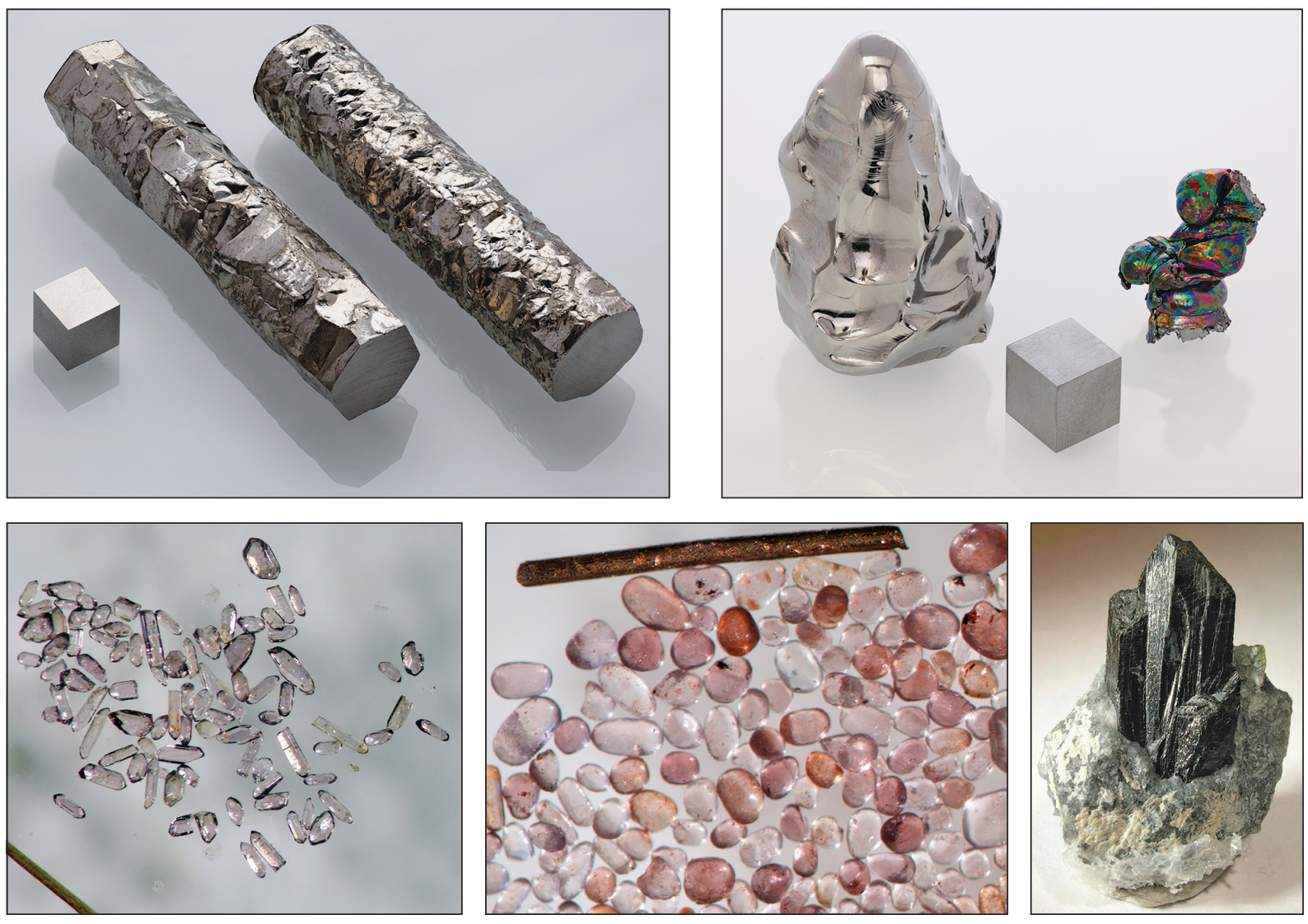

Professional Paper 1802-V 


\section{Periodic Table of Elements}

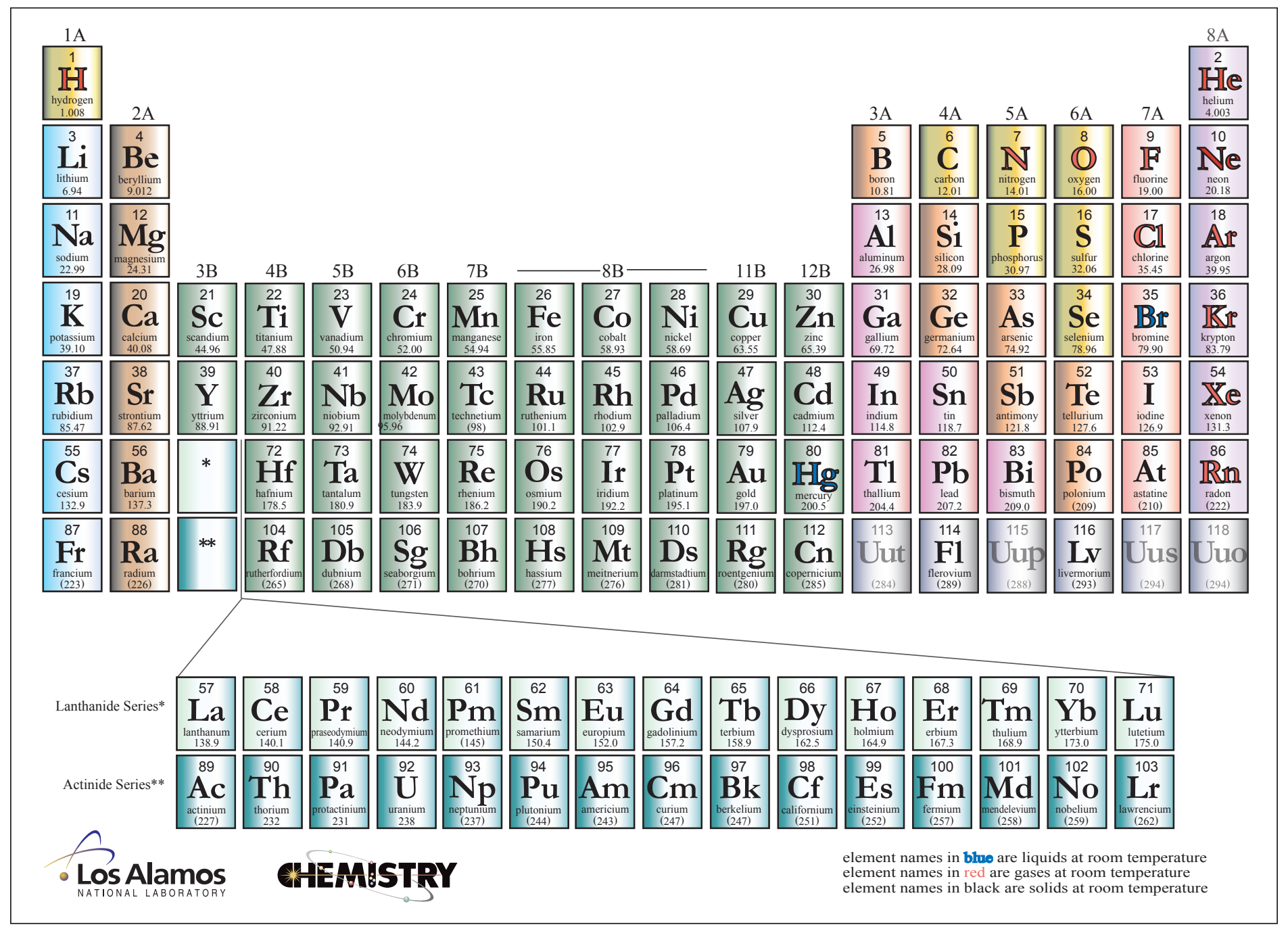

Modified from Los Alamos National Laboratory Chemistry Division; available at http://periodic.lanl.gov/images/periodictable.pdf.

Cover. Photographs showing examples of sources and uses of zirconium and hafnium. Upper left, cube and crystal bars of highly pure zirconium metal (greater than 99.95 percent purity). Upper right, a pure $(99.98$ percent) melted tip of a hafnium electrode used in an electron beam remelting furnace for manufacturing metal parts; an oxidized hafnium electron beam remelted ingot; and a cubic centimeter of hafnium metal. Photographs by Heinrich Pniok (http://pse-mendelejew.de). Lower left, primary igneous zircon grains separated from granite. Lower middle, detrital zircon grains separated from metamorphosed sandstone. Lower right, baddeleyite crystals from the Palabora carbonatite deposit, Limpopo Province, South Africa. Photographs by Rob Lavinsky (www.iRocks.com). 


\section{Zirconium and Hafnium}

By James V. Jones III, Nadine M. Piatak, and George M. Bedinger

Chapter V of

Critical Mineral Resources of the United States-Economic and Environmental Geology and Prospects for Future Supply

Edited by Klaus J. Schulz, John H. DeYoung, Jr., Robert R. Seal II, and Dwight C. Bradley

Professional Paper 1802-V

U.S. Department of the Interior

U.S. Geological Survey 


\title{
U.S. Department of the Interior RYAN K. ZINKE, Secretary
}

\section{U.S. Geological Survey William H. Werkheiser, Acting Director}

\author{
U.S. Geological Survey, Reston, Virginia: 2017
}

For more information on the USGS — the Federal source for science about the Earth, its natural and living resources, natural hazards, and the environment-visit https://www.usgs.gov or call 1-888-ASK-USGS.

For an overview of USGS information products, including maps, imagery, and publications, visit https://store.usgs.gov/.

Any use of trade, firm, or product names is for descriptive purposes only and does not imply endorsement by the U.S. Government.

Although this information product, for the most part, is in the public domain, it also may contain copyrighted materials as noted in the text. Permission to reproduce copyrighted items must be secured from the copyright owner.

Suggested citation:

Jones, J.V., III, Piatak, N.M., and Bedinger, G.M., 2017, Zirconium and hafnium, chap. V of Schulz, K.J., DeYoung, J.H., Jr., Seal, R.R., II, and Bradley, D.C., eds., Critical mineral resources of the United States-Economic and environmental geology and prospects for future supply: U.S. Geological Survey Professional Paper 1802, p. V1-V26, https://doi.org/ 10.3133/pp1802V.

ISSN 2330-7102 (online) 


\section{Contents}

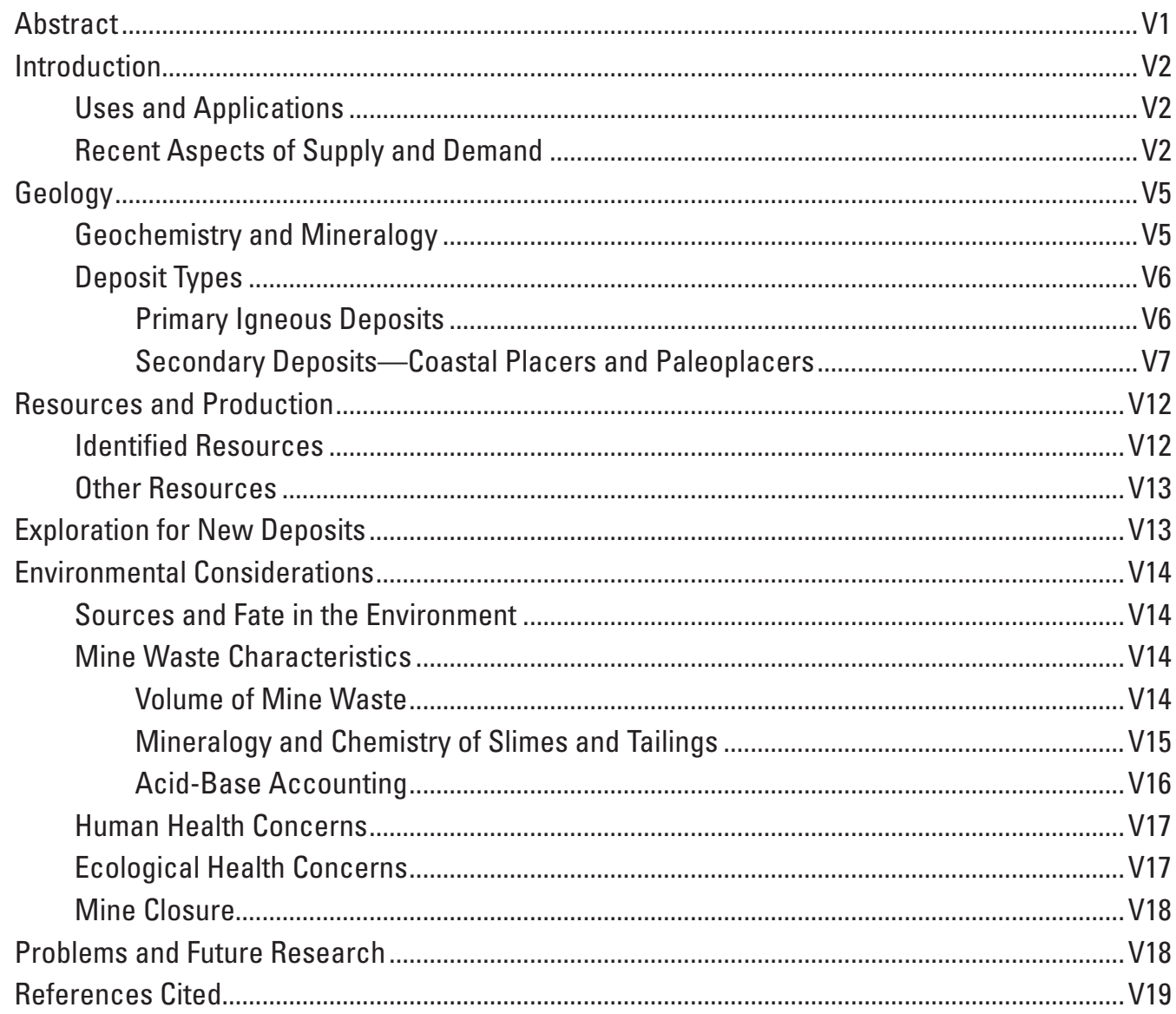

\section{Figures}

V1. Examples of sources and uses of zirconium and hafnium .........................................V3

V2. Graphs showing global zirconium production and U.S. trade information for zirconium ores and concentrates ................................................................................. V4

V3. World map showing locations of selected zirconium and hafnium deposits and regions with modern coastal placer systems

V4. Diagrams showing examples of coastal depositional systems with an emphasis on barrier island location, morphology, and depositional environments ..................... V10

V5. Diagrams showing influences on and locations of placer formation in coastal environments. 


\section{Conversion Factors}

International System of Units to Inch/Pound

\begin{tabular}{|c|c|c|}
\hline Multiply & By & To obtain \\
\hline \multicolumn{3}{|c|}{ Length } \\
\hline angstrom $(\AA)$ (0.1 nanometer) & 0.003937 & microinch \\
\hline $\operatorname{angstrom}(\AA)$ (0.1 nanometer) & 0.000003937 & mil \\
\hline micrometer $(\mu \mathrm{m})$ [or micron] & 0.03937 & mil \\
\hline millimeter (mm) & 0.03937 & inch (in.) \\
\hline centimeter $(\mathrm{cm})$ & 0.3937 & inch (in.) \\
\hline meter $(\mathrm{m})$ & 3.281 & foot $(\mathrm{ft})$ \\
\hline meter $(\mathrm{m})$ & 1.094 & yard (yd) \\
\hline kilometer $(\mathrm{km})$ & 0.6214 & mile (mi) \\
\hline \multicolumn{3}{|c|}{ Area } \\
\hline hectare (ha) & 2.471 & acre \\
\hline square kilometer $\left(\mathrm{km}^{2}\right)$ & 247.1 & acre \\
\hline square meter $\left(\mathrm{m}^{2}\right)$ & 10.76 & square foot $\left(\mathrm{ft}^{2}\right)$ \\
\hline square centimeter $\left(\mathrm{cm}^{2}\right)$ & 0.1550 & square inch $\left(\mathrm{ft}^{2}\right)$ \\
\hline square kilometer $\left(\mathrm{km}^{2}\right)$ & 0.3861 & square mile $\left(\mathrm{mi}^{2}\right)$ \\
\hline \multicolumn{3}{|c|}{ Volume } \\
\hline milliliter (mL) & 0.03381 & ounce, fluid (fl. oz) \\
\hline liter $(\mathrm{L})$ & 33.81402 & ounce, fluid (fl. oz) \\
\hline liter (L) & 1.057 & quart $(\mathrm{qt})$ \\
\hline liter $(\mathrm{L})$ & 0.2642 & gallon (gal) \\
\hline cubic meter $\left(\mathrm{m}^{3}\right)$ & 264.2 & gallon (gal) \\
\hline cubic centimeter $\left(\mathrm{cm}^{3}\right)$ & 0.06102 & cubic inch $\left(\mathrm{in}^{3}\right)$ \\
\hline cubic meter $\left(\mathrm{m}^{3}\right)$ & 1.308 & cubic yard $\left(\mathrm{yd}^{3}\right)$ \\
\hline cubic kilometer $\left(\mathrm{km}^{3}\right)$ & 0.2399 & cubic mile $\left(\mathrm{mi}^{3}\right)$ \\
\hline \multicolumn{3}{|c|}{ Mass } \\
\hline microgram $(\mu \mathrm{g})$ & 0.00000003527 & ounce, avoirdupois (oz) \\
\hline milligram (mg) & 0.00003527 & ounce, avoirdupois (oz) \\
\hline $\operatorname{gram}(\mathrm{g})$ & 0.03527 & ounce, avoirdupois (oz) \\
\hline $\operatorname{gram}(\mathrm{g})$ & 0.03215075 & ounce, troy \\
\hline kilogram (kg) & 32.15075 & ounce, troy \\
\hline kilogram (kg) & 2.205 & pound avoirdupois (lb) \\
\hline ton, metric $(\mathrm{t})$ & 1.102 & ton, short $[2,000 \mathrm{lb}]$ \\
\hline ton, metric $(\mathrm{t})$ & 0.9842 & ton, long $[2,240 \mathrm{lb}]$ \\
\hline \multicolumn{3}{|c|}{ Deposit grade } \\
\hline gram per metric ton $(\mathrm{g} / \mathrm{t})$ & 0.0291667 & ounce per short ton $(2,000 \mathrm{lb})(\mathrm{oz} / \mathrm{T})$ \\
\hline \multicolumn{3}{|c|}{ Pressure } \\
\hline megapascal (MPa) & 10 & bar \\
\hline gigapascal (GPa) & 10,000 & bar \\
\hline \multicolumn{3}{|c|}{ Density } \\
\hline gram per cubic centimeter $\left(\mathrm{g} / \mathrm{cm}^{3}\right)$ & 62.4220 & pound per cubic foot $\left(\mathrm{lb} / \mathrm{ft}^{3}\right)$ \\
\hline milligram per cubic meter $\left(\mathrm{mg} / \mathrm{m}^{3}\right)$ & 0.00000006243 & pound per cubic foot $\left(\mathrm{lb} / \mathrm{ft}^{3}\right)$ \\
\hline \multicolumn{3}{|c|}{ Energy } \\
\hline joule (J) & 0.0000002 & kilowatthour (kWh) \\
\hline joule $(\mathrm{J})$ & $6.241 \times 10^{18}$ & electronvolt (eV) \\
\hline joule $(\mathrm{J})$ & 0.2388 & calorie (cal) \\
\hline kilojoule (kJ) & 0.0002388 & kilocalorie (kcal) \\
\hline
\end{tabular}


International System of Units to Inch/Pound - Continued

\begin{tabular}{|c|c|c|}
\hline Multiply & By & To obtain \\
\hline \multicolumn{3}{|c|}{ Radioactivity } \\
\hline becquerel $(\mathrm{Bq})$ & 0.00002703 & microcurie $(\mu \mathrm{Ci})$ \\
\hline kilobecquerel (kBq) & 0.02703 & microcurie $(\mu \mathrm{Ci})$ \\
\hline \multicolumn{3}{|c|}{ Electrical resistivity } \\
\hline ohm meter $(\Omega-\mathrm{m})$ & 39.37 & ohm inch $(\Omega$-in. $)$ \\
\hline ohm-centimeter $(\Omega$-cm) & 0.3937 & ohm inch $(\Omega$-in.) \\
\hline \multicolumn{3}{|c|}{ Thermal conductivity } \\
\hline $\begin{array}{l}\text { watt per centimeter per degree } \\
\left.\text { Celsius (watt } / \mathrm{cm}^{\circ} \mathrm{C}\right)\end{array}$ & 693.1798 & $\begin{array}{l}\text { International British thermal unit } \\
\text { inch per hour per square foot per } \\
\text { degree Fahrenheit }\left(\mathrm{Btu} \text { in } / \mathrm{h} \mathrm{ft}^{2}{ }^{\circ} \mathrm{F}\right)\end{array}$ \\
\hline watt per meter kelvin (W/m-K) & 6.9318 & $\begin{array}{l}\text { International British thermal unit } \\
\text { inch per hour per square foot per } \\
\text { degree Fahrenheit (Btu in } / \mathrm{h} \mathrm{ft}{ }^{\circ} \mathrm{F} \text { ) }\end{array}$ \\
\hline
\end{tabular}

Inch/Pound to International System of Units

\begin{tabular}{|c|c|c|}
\hline \multicolumn{3}{|c|}{ Length } \\
\hline mil & 25.4 & micrometer $(\mu \mathrm{m})$ [or micron] \\
\hline inch (in.) & 2.54 & centimeter $(\mathrm{cm})$ \\
\hline inch (in.) & 25.4 & millimeter (mm) \\
\hline foot $(\mathrm{ft})$ & 0.3048 & meter $(\mathrm{m})$ \\
\hline mile (mi) & 1.609 & kilometer (km) \\
\hline \multicolumn{3}{|c|}{ Volume } \\
\hline ounce, fluid (fl. oz) & 29.57 & milliliter $(\mathrm{mL})$ \\
\hline ounce, fluid (fl. oz) & 0.02957 & liter $(\mathrm{L})$ \\
\hline \multicolumn{3}{|c|}{ Mass } \\
\hline ounce, avoirdupois (oz) & $28,350,000$ & microgram \\
\hline ounce, avoirdupois (oz) & 28,350 & milligram \\
\hline ounce, avoirdupois (oz) & 28.35 & $\operatorname{gram}(\mathrm{g})$ \\
\hline ounce, troy & 31.10348 & $\operatorname{gram}(\mathrm{g})$ \\
\hline ounce, troy & 0.03110348 & kilogram (kg) \\
\hline pound, avoirdupois (lb) & 0.4536 & kilogram (kg) \\
\hline ton, short $(2,000 \mathrm{lb})$ & 0.9072 & ton, metric $(\mathrm{t})$ \\
\hline ton, long $(2,240 \mathrm{lb})$ & 1.016 & ton, metric $(\mathrm{t})$ \\
\hline \multicolumn{3}{|c|}{ Deposit grade } \\
\hline ounce per short ton $(2,000 \mathrm{lb})(\mathrm{oz} / \mathrm{T})$ & 34.285714 & gram per metric ton $(\mathrm{g} / \mathrm{t})$ \\
\hline \multicolumn{3}{|c|}{ Energy } \\
\hline kilowatthour (kWh) & $3,600,000$ & joule $(\mathrm{J})$ \\
\hline electronvolt $(\mathrm{eV})$ & $1.602 \times 10^{-19}$ & joule $(\mathrm{J})$ \\
\hline \multicolumn{3}{|c|}{ Radioactivity } \\
\hline microcurie $(\mu \mathrm{Ci})$ & 37,000 & becquerel (Bq) \\
\hline microcurie $(\mu \mathrm{Ci})$ & 37 & kilobecquerel (kBq) \\
\hline
\end{tabular}

Temperature in degrees Celsius $\left({ }^{\circ} \mathrm{C}\right)$ may be converted to degrees Fahrenheit $\left({ }^{\circ} \mathrm{F}\right)$ as follows:

$$
{ }^{\circ} \mathrm{F}=\left(1.8 \times{ }^{\circ} \mathrm{C}\right)+32
$$

Temperature in degrees Celsius $\left({ }^{\circ} \mathrm{C}\right)$ may be converted to kelvin $(\mathrm{K})$ as follows:

$$
\mathrm{K}={ }^{\circ} \mathrm{C}+273.15
$$

Temperature in degrees Fahrenheit $\left({ }^{\circ} \mathrm{F}\right)$ may be converted to degrees Celsius $\left({ }^{\circ} \mathrm{C}\right)$ as follows:

$$
{ }^{\circ} \mathrm{C}=\left({ }^{\circ} \mathrm{F}-32\right) / 1.8
$$




\section{Datum}

Unless otherwise stated, vertical and horizontal coordinate information is referenced to the World Geodetic System of 1984 (WGS 84). Altitude, as used in this report, refers to distance above the vertical datum.

\section{Supplemental Information}

Specific conductance is given in microsiemens per centimeter at 25 degrees Celsius $(\mu \mathrm{S} / \mathrm{cm}$ at $\left.25^{\circ} \mathrm{C}\right)$.

Concentrations of chemical constituents in soils and (or) sediment are given in milligrams per kilogram (mg/kg), parts per million (ppm), or parts per billion (ppb).

Concentrations of chemical constituents in water are given in milligrams per liter $(\mathrm{mg} / \mathrm{L})$, micrograms per liter $(\mu \mathrm{g} / \mathrm{L})$, nanogams per liter $(\mathrm{ng} / \mathrm{L})$, nanomoles per kilogram $(\mathrm{nmol} / \mathrm{kg})$, parts per million (ppm), parts per billion (ppb), or parts per trillion (ppt).

Concentrations of suspended particulates in water are given in micrograms per gram $(\mu \mathrm{g} / \mathrm{g})$, milligrams per kilogram $(\mathrm{mg} / \mathrm{kg})$, or femtograms per gram $(\mathrm{fg} / \mathrm{g})$.

Concentrations of chemicals in air are given in units of the mass of the chemical (milligrams, micrograms, nanograms, or picograms) per volume of air (cubic meter).

Activities for radioactive constituents in air are given in microcuries per milliliter $(\mu \mathrm{Ci} / \mathrm{mL})$.

Deposit grades are commonly given in percent, grams per metric ton $(\mathrm{g} / \mathrm{t})$ - which is equivalent to parts per million (ppm) — or troy ounces per short ton (oz/T).

Geologic ages are expressed in mega-annum ( $\mathrm{Ma}$, million years before present, or $10^{6}$ years ago) or giga-annum ( $\mathrm{Ga}$, billion years before present, or $10^{9}$ years ago).

For ranges of years, "to" and (or) the en dash ("-") mean "up to and including."

\begin{tabular}{ll}
\multicolumn{1}{c}{ Concentration unit } & \multicolumn{1}{c}{ Equals } \\
\hline milligram per kilogram $(\mathrm{mg} / \mathrm{kg})$ & part per million \\
microgram per gram $(\mu \mathrm{g} / \mathrm{g})$ & part per million \\
microgram per kilogram $(\mu \mathrm{g} / \mathrm{kg})$ & part per billion $\left(10^{9}\right)$ \\
\hline
\end{tabular}

\section{Equivalencies}

part per million $(\mathrm{ppm}): 1 \mathrm{ppm}=1,000 \mathrm{ppb}=1,000,000 \mathrm{ppt}=0.0001$ percent part per billion (ppb): $0.001 \mathrm{ppm}=1 \mathrm{ppb}=1,000 \mathrm{ppt}=0.0000001$ percent part per trillion (ppt): $0.000001 \mathrm{ppm}=0.001 \mathrm{ppb}=1 \mathrm{ppt}=0.0000000001$ percent

\section{Metric system prefixes}

$\begin{array}{lll}\text { tera- (T-) } & 10^{12} & 1 \text { trillion } \\ \text { giga- (G-) } & 10^{9} & 1 \text { billion } \\ \text { mega- (M-) } & 10^{6} & 1 \text { million } \\ \text { kilo- (k-) } & 10^{3} & 1 \text { thousand } \\ \text { hecto- (h-) } & 10^{2} & 1 \text { hundred } \\ \text { deka- (da-) } & 10 & 1 \text { ten } \\ \text { deci- (d-) } & 10^{-1} & 1 \text { tenth } \\ \text { centi- (c-) } & 10^{-2} & 1 \text { hundredth } \\ \text { milli- (m-) } & 10^{-3} & 1 \text { thousandth } \\ \text { micro- ( } \mu-) & 10^{-6} & 1 \text { millionth } \\ \text { nano- (n-) } & 10^{-9} & 1 \text { billionth } \\ \text { pico- (p-) } & 10^{-12} & 1 \text { trillionth } \\ \text { femto- (f-) } & 10^{-15} & 1 \text { quadrillionth } \\ \text { atto- (a-) } & 10^{-18} & 1 \text { quintillionth }\end{array}$




\section{Abbreviations and Symbols}

${ }^{\circ} \mathrm{C}$

$\mu \mathrm{g} / \mathrm{L}$

ATSDR

$\mathrm{cm}^{3}$

EPA

HFSE

IARC

$\mathrm{kg} \mathrm{CaCO} / \mathrm{t}$

$\mathrm{km}$

$\mathrm{km}^{2}$

$\mathrm{LC}_{50}$

m

$\mathrm{mg} / \mathrm{kg}$

$\mathrm{mm}$

m.y.

$\mathrm{ng} / \mathrm{m}^{3}$

$\mathrm{ppb}$

ppm

ppt

REE

WHO degree Celsius

microgram per liter

Agency for Toxic Substances and Disease Registry

cubic centimeter

U.S. Environmental Protection Agency

high-field-strength element

International Agency for Research on Cancer

kilogram of calcium carbonate per metric ton

kilometer

square kilometer

lethal concentration 50 (concentration that kills 50 percent of test population within a given timeframe)

meter

milligram per kilogram

millimeter

million years

nanogram per cubic meter

part per billion

part per million

part per trillion

rare-earth element

World Health Organization 



\title{
Zirconium and Hafnium
}

\author{
By James V. Jones III, Nadine M. Piatak, and George M. Bedinger
}

\section{Abstract}

Zirconium and hafnium are corrosion-resistant metals that are widely used in the chemical and nuclear industries. Most zirconium is consumed in the form of the main ore mineral zircon $\left(\mathrm{ZrSiO}_{4}\right)$, or as zirconium oxide or other zirconium chemicals. Zirconium and hafnium are both refractory lithophile elements that have nearly identical charge, ionic radii, and ionic potentials. As a result, their geochemical behavior is generally similar. Both elements are classified as incompatible because they have physical and crystallochemical properties that exclude them from the crystal lattices of most rock-forming minerals. Zircon and another, less common, ore mineral, baddeleyite $\left(\mathrm{ZrO}_{2}\right)$, form primarily as accessory minerals in igneous rocks. The presence and abundance of these ore minerals in igneous rocks are largely controlled by the element concentrations in the magma source and by the processes of melt generation and evolution. The world's largest primary deposits of zirconium and hafnium are associated with alkaline igneous rocks, and, in one locality on the Kola Peninsula of Murmanskaya Oblast, Russia, baddeleyite is recovered as a byproduct of apatite and magnetite mining. Otherwise, there are few primary igneous deposits of zirconium- and hafnium-bearing minerals with economic value at present. The main ore deposits worldwide are heavy-mineral sands produced by the weathering and erosion of preexisting rocks and the concentration of zircon and other economically important heavy minerals, such as ilmenite and rutile (for titanium), chromite (for chromium), and monazite (for rareearth elements) in sedimentary systems, particularly in coastal environments. In coastal deposits, heavy-mineral enrichment occurs where sediment is repeatedly reworked by wind, waves, currents, and tidal processes. The resulting heavy-mineral sand deposits, called placers or paleoplacers, preferentially form at relatively low latitudes on passive continental margins and supply 100 percent of the world's zircon. Zircon makes up a relatively small percentage of the economic heavy minerals in most deposits and is produced primarily as a byproduct of heavy-mineral sand mining for titanium minerals.
From 2003 to 2012, world zirconium mineral concentrates production increased by more than 40 percent, and Australia and South Africa were the leading producers. Global consumption of zirconium mineral concentrates generally increased during the same time period, largely as a result of increased demand in developing economies in Asia and the Middle East. Global demand weakened in 2012, causing a decrease in world production of zirconium mineral concentrates and delaying the development of several new mining projects. Global consumption is expected to increase in the future, however, as demand from the ceramics, chemicals, and metals industries increases (driven by renewed growth in developing economies) and demand for zirconium and hafnium metal increases (driven by the construction and operation of new nuclear powerplants).

The behaviors of zirconium and hafnium in the environment are very similar to one another in that most zirconium- and hafnium-bearing minerals have limited solubility and reactivity. Anthropogenic sources of zirconium, and likely hafnium, are from industrial zirconium-containing byproducts and emissions from the processing of sponge zirconium, and exposure to the general population from these sources is small. Zirconium and hafnium are likely not essential to human health and generally are considered to be of low toxicity to humans. The main exposure risks are associated with industrial inhalation and dermal exposure. Because of the low solubility of zirconium and hafnium, ecological health concerns in the aquatic environment and in soils are minimal. Heavy-mineral sand mining may lead to increased erosion rates when the mining is managed improperly. In addition, surface mining requires removal of the overlying organic soil layer and produces waste material that includes tailings and slimes. The soil removal and mining activity disturbs the surrounding ecosystem and alters the character of the landscape. Dry mineral separation processes create high amounts of airborne dust, whereas wet mineral separation processes do not. In operations that restore the landscape to pre-mining conditions, the volume of waste and the impact on the landscape may be relatively temporary. 


\section{V2 Critical Mineral Resources of the United States-Zirconium and Hafnium}

\section{Introduction}

\section{Uses and Applications}

Zirconium (Zr) and hafnium (Hf) are metals (figs. V1A and $\mathrm{V} 1 B$, respectively) that are used in the chemical and nuclear-reactor industries in applications for which corrosion resistance, structural stability at high temperatures, and specific alloying properties and (or) specific neutronabsorption characteristics are required. The main ore mineral for both elements is zircon $\left(\mathrm{ZrSiO}_{4}\right)$ (figs. $\mathrm{V} 1 C$ and $\mathrm{V} 1 D$ ), which typically has a zirconium to hafnium ( $\mathrm{Zr}: \mathrm{Hf}$ ) ratio of 50:1. Baddeleyite $\left(\mathrm{ZrO}_{2}\right)$ (fig. V1E) is a less common but commercially important mineral that contains both zirconium and hafnium, but in a ratio of approximately 73:1. Zircon and baddeleyite are formed primarily as accessory minerals in igneous rocks and are typically present at relatively low abundances. They also occur naturally in a wide variety of rock types and geologic environments. The main ore deposits worldwide are heavy-mineral sands (figs. $\mathrm{V} 1 F$ and $\mathrm{V} 1 G$ ) produced by the weathering and erosion of preexisting rocks and the concentration of zircon in sedimentary systems, particularly in coastal environments.

Approximately 95 percent of all zirconium consumed is in the form of zircon, zirconium oxide, or other zirconium chemicals (Nielson and Wilfling, 2002; Gambogi, 2012b). Zircon is highly refractive, with a melting point of 2,550 degrees Celsius $\left({ }^{\circ} \mathrm{C}\right)$ or greater. Thus, zircon is used for facings on foundry molds, and milled or ground zircon is used in refractory paints for coating the surfaces of molds. Zircon bricks and blocks are used in furnaces and hearths for containing molten metals, and glass tank furnaces use fused-cast and bonded alumina-zirconia-silica-based refractory metal. Zircon is also used in minor quantities as a gemstone and may be processed to produce cubic zirconia, which is a synthetic gemstone and diamond simulant. Baddeleyite is used in the manufacture of alumina-zirconia abrasives and in ceramic colors and refractories.

Zirconia, which is a form of zirconium oxide, is produced by reacting zircon ore with caustic soda and then chlorinating it to produce zirconium oxychloride. The zirconium oxychloride is then calcined and precipitated to form zirconia powder. Zirconia has a high melting point $\left(2,700^{\circ} \mathrm{C}\right)$ and low thermal conductivity, and it is an important constituent of ceramic colors and glazes. Zirconia undergoes a phase transformation during heating, however, and must be stabilized for other uses by adding such oxides as calcium oxide $(\mathrm{CaO})$, magnesium oxide $(\mathrm{MgO})$, and yttrium oxide (yttria; $\mathrm{Y}_{2} \mathrm{O}_{3}$ ) into the zirconia structure. Yttria-stabilized zirconia is used in the manufacture of cubic zirconia, fiber-optic connector components, refractory coatings, engineering and structural ceramics, and oxygen sensors that control combustion in automobile engines. Because it has increased fracture resistance and strength relative to similar alumina products, yttria-stabilized zirconia is also used in dental applications, such as bridges, crowns, and inlays, and in joint-replacement procedures. Other zirconium chemicals include the following: zirconium boride used as a diffusion barrier in semiconductors, as a container for molten metals, and as a burnable absorber in nuclear reactor cores; zirconium carbonates used in antiperspirants and in printing and paper manufacturing; zirconium hydride used for flares, fuses, and combustion charges in pyrotechnics and as a binding or brazing component in abrasive wheels and polishing discs; zirconium nitride used as a wear-resistant coating on drill and tool bits; zirconium phosphates used for cation exchange applications, such as dialysis, drug delivery, and nuclear waste management; and zirconium sulfates used in leather tanning, as catalysts, and as coatings for titanium oxide pigment powder (Nielson and Wilfling, 2002).

Zirconium and hafnium metals are produced by the Kroll process, which involves reduction of zirconium oxychloride by magnesium metal in an inert atmosphere. The resulting metal contains a mixture of zirconium and up to 2 percent hafnium and is used for nonnuclear applications in corrosive environments and in specialty alloys. For nuclear-grade applications, the metals must be separated because of their different neutron absorption characteristics. Hafnium-free zirconium metal has a low thermal neutron-absorption cross section, so it is used for structural materials in nuclear reactors and as cladding for nuclear fuel rods. Hafnium has a relatively high thermal neutron absorption cross section and thus is used in nuclear control rods. Reactor-grade zirconium and hafnium are produced by dissolving zirconium oxychloride and chemically separating the hafnium from the solution. The zirconium and hafnium components are separately processed to form chlorides, which are then reduced to metals by the Kroll process. Hafnium is also used in high-temperature ceramics, nickel-base superalloys, and nozzles for plasma arc metal cutting.

\section{Recent Aspects of Supply and Demand}

Global production of zirconium mineral concentrates increased by more than 50 percent between 2003 and 2012 (fig. V2A); the main source of the output was zircon from heavy-mineral sands. A relatively small quantity of zirconium was derived from baddeleyite produced from a single source on the Kola Peninsula of Murmanskaya Oblast, Russia. Excluding the United States, world production reached approximately 1.68 million metric tons of zirconium mineral concentrates in 2011, followed by a significant decrease to 1.45 million metric tons in 2012 (fig. V2A; U.S. Geological Survey, 2014). In 2012, Australia and South Africa were the leading world zircon producers, accounting for approximately 70 percent of all production outside of the United States (fig. V2B; Bedinger, 2015a). China was the leading consuming country.

Global consumption of zircon increased in 2011, largely as a result of increased demand in developing economies in Asia and the Middle East (Gambogi, 2012b), and the prices of zirconium ores and concentrates rose dramatically during the same period. In 2011, prices of domestic standard-grade bulk zircon increased to between $\$ 2,550$ and $\$ 2,750$ per metric ton 

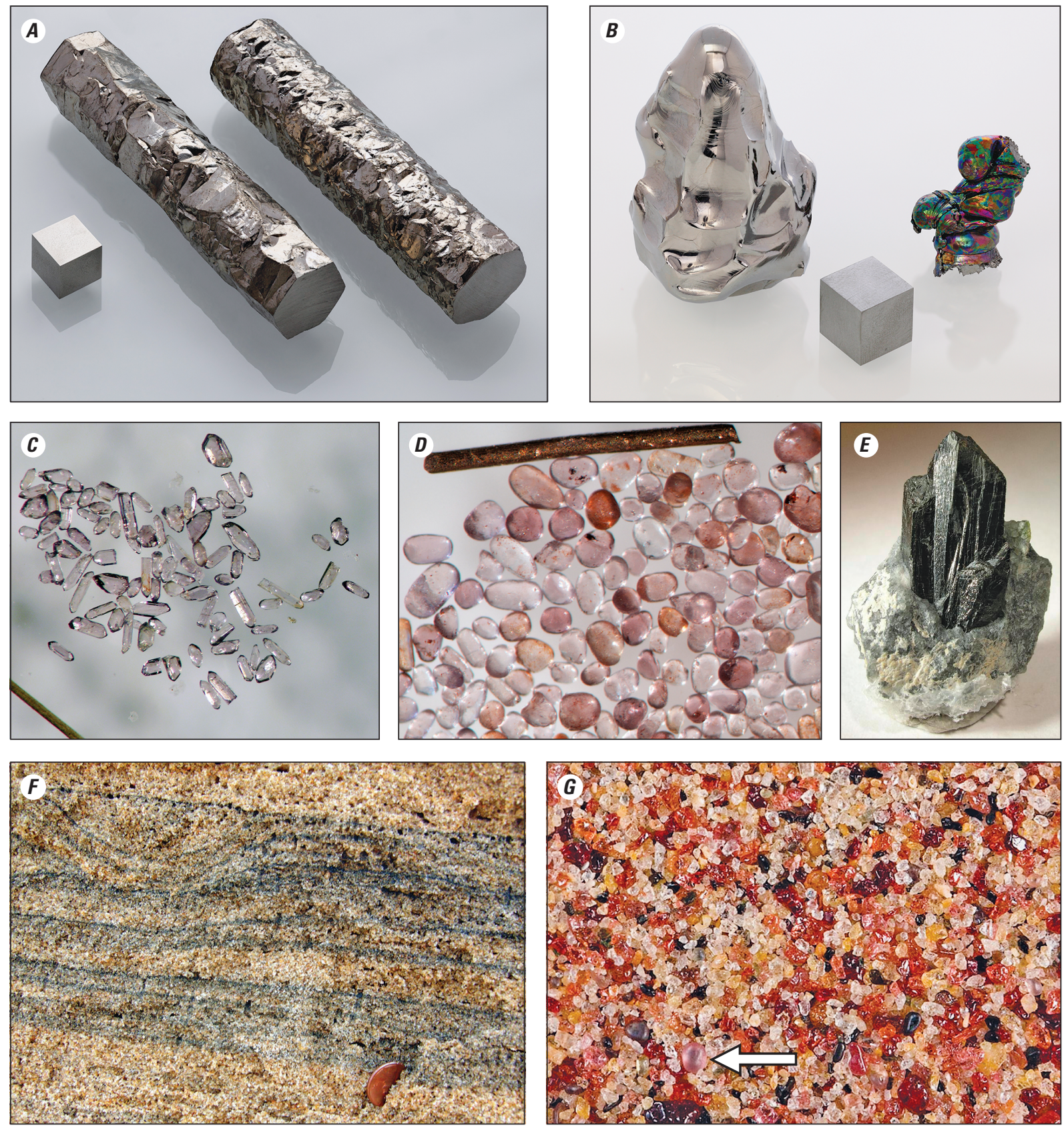

Figure V1. Examples of sources and uses of zirconium and hafnium. $A$, Cube and crystal bars of highly pure zirconium metal (greater than 99.95 percent purity). The cube is 1 cubic centimeter in volume. $B$, (left) A pure (99.98 percent) melted tip of a hafnium electrode used in an electron beam remelting furnace for manufacturing metal parts; (right) an oxidized hafnium electron beam remelted ingot (color is from thin film effects in the oxide layer); and (center) a cubic centimeter of hafnium metal. Photographs $A$ and $B$ are by Heinrich Pniok (http://pse-mendelejew.de). C, Primary igneous zircon grains separated from granite. Note the prismatic character of most of the grains and the double termination on some. The wire (for scale) in the lower left-hand corner of the photograph is approximately 0.1 millimeter $(\mathrm{mm})$ in diameter. $D$, Detrital zircon grains separated from metamorphosed sandstone. The rounding of the grains likely occurred during sedimentary transport and reworking. The wire (for scale) at the top of the photograph is approximately $0.1 \mathrm{~mm}$ in diameter. Photographs $C$ and $D$ are by James V. Jones. E, Baddeleyite crystals from the Palabora carbonatite deposit, Limpopo Province, South Africa. Photograph by Rob Lavinsky (www.iRocks.com). F, Heavy-mineral concentrations (dark seams) in weakly indurated outcrops of quartz beach sand from Chennai, India. The penny embedded in the sand (lower right) is for scale. Photograph by Mark Wilson (College of Wooster, Ohio). G, Photomicrograph of heavy-mineral sands from Sri Lanka that are rich in red to brown spinel. Note the larger, well-rounded pink zircon grain indicated by the white arrow. The width of the view is $20 \mathrm{~mm}$. Photograph by Simm Sepp (www.sandatlas.org). 
from between $\$ 830$ and $\$ 890$ per metric ton (fig. V2C; Loferski, 2013a). The average unit value of imported zirconium ore and concentrates (primarily zircon sand) was $\$ 2,170$ per metric ton in 2011 (fig. V2C; Loferski, 2013a). The subsequent decrease in world production of zirconium mineral concentrates in 2012 was in response to weakened demand, particularly in China, because of a slowdown in housing construction. Global consumption of zirconium mineral concentrates is expected to increase in the future, as demand from such consumers as the ceramics, chemicals, and metals industries increases, driven by renewed growth in developing economies. Construction and operation of new nuclear powerplants throughout the world are also expected to result in future demand increases for zirconium and hafnium metal. Although new zircon mines were brought online in recent years, the global financial situation led to decreased production and delayed the development of several mining projects. Thus, constricted supply together with the projected increase in demand could create a scarcity of zircon in the future (Loferski, 2013a). Despite this possibility, zirconium ranks relatively low on the British Geological Survey's risk list, possibly reflecting the political and (or) economic stability of the countries that are major sources of this mineral commodity and the fact that production comes from several areas worldwide (British Geological Survey, 2012).

Figure V2. Graphs showing global zirconium production (not including U.S. production) and U.S. trade information for zirconium ores and concentrates. $A$, World zirconium mine production from 2003 to 2012. Data are from Gambogi (2010), U.S. Geological Survey (2010-13), and Bedinger (2014). B, Global zirconium mine production, by country, from 2007 to 2012. Data are from U.S. Geological Survey (2010-13) and Bedinger (2014).

$C$, U.S. exports and imports of zirconium ores and concentrates, by amount, value, and price, from 2003 to 2011. Data are from U.S. Geological Survey (2006-9, 2010-13), Gambogi (2010), and Bedinger (2014).

\section{A. World zirconium mineral concentrates mine production ${ }^{1}$}

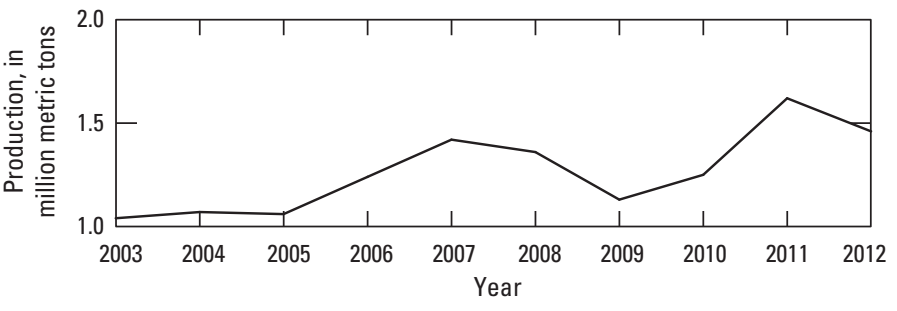

\section{B. Zirconium mineral concentrates mine production by country ${ }^{1}$}

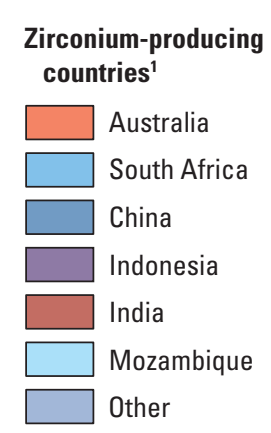

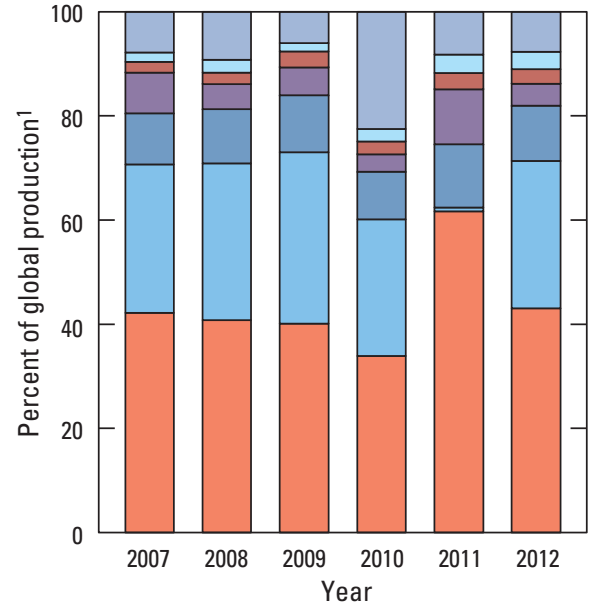

\section{Amount, value, and price of U.S. exports and imports of} zirconium ores and concentrates
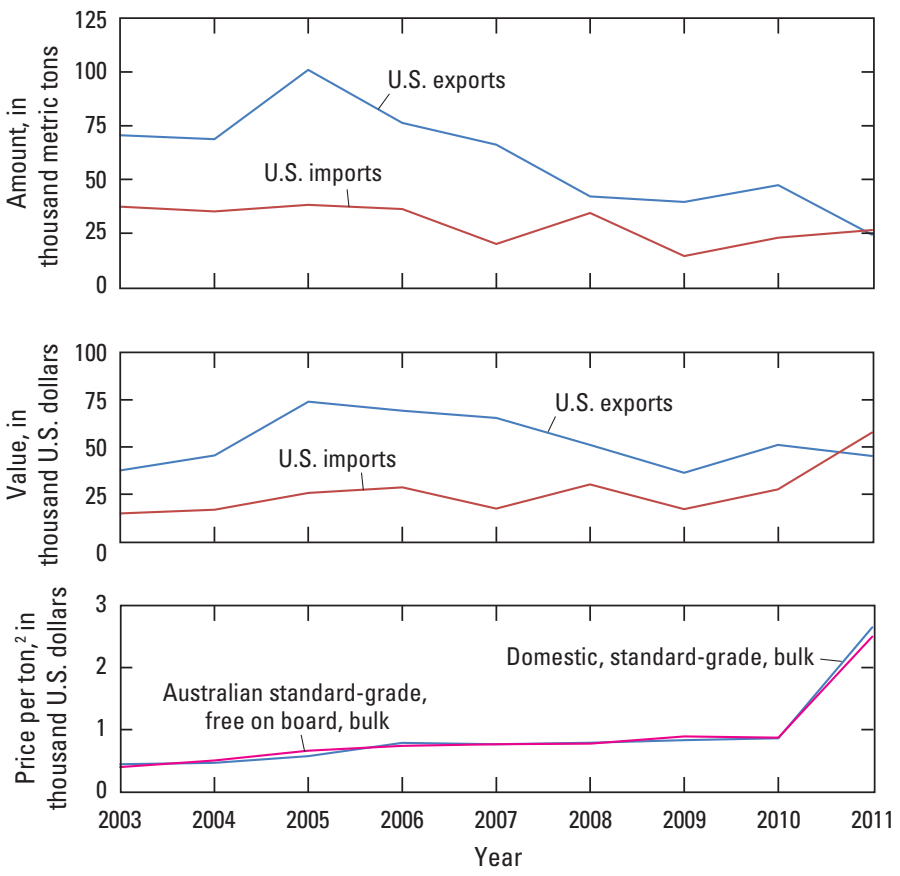

${ }^{1}$ Does not include the United States

${ }^{2}$ Average price 


\section{Geology}

\section{Geochemistry and Mineralogy}

Zirconium and hafnium are refractory lithophile elements that have nearly identical charge, ionic radii, and ionic potentials. They are classified as incompatible elements because they have physical and crystallochemical properties that exclude them from the crystal lattices of most rockforming minerals. In particular, zirconium and hafnium cations have relatively high charges $\left(\mathrm{Zr}^{4+}\right.$ and $\left.\mathrm{Hf}^{4+}\right)$ and small ionic radii. Thus, they and other similar elements, such as niobium, thorium, and uranium, develop intense electrostatic fields and do not substitute for the major elements in ordinary minerals. Instead, these elements, known as high field-strength elements (HFSE), concentrate in less common accessory minerals. Zirconium and hafnium are enriched in Earth's crust relative to the mantle and have estimated average crustal abundances of 100 parts per million (ppm) and 3 ppm, respectively (Taylor and McLennan, 1995). Both elements are concentrated in the upper crust relative to the lower crust by a factor of approximately 1.5 (Taylor and McLennan, 1995).

Zircon $\left(\mathrm{ZrSiO}_{4}\right)$ is the most common naturally occurring zirconium- and hafnium-bearing mineral. Most zircon forms as a product of primary crystallization in igneous rocks; in most rocks, zircon is the main mineral and zirconium is an essential structural constituent (Hoskin and Schaltegger, 2003). Most natural zircon has a $\mathrm{Zr}$ :Hf ratio of 33.6:1, which is about the same as the average crustal abundance ratio of those elements (Taylor and McLennan, 1995). The hafnium content of zircon can vary widely, however (from 6,000 to 11,600 ppm) (Ahrens and Erlank, 1969; Heaman and others, 1990), depending on the composition of the magma from which the zircon crystallized.

The natural color of zircon crystals varies from colorless to yellow, reddish-pink, purple, brown, blue, and green. Crystal sizes range in diameter and length from microns to a few centimeters, and well-formed zircon crystals are foursided prisms terminated by pyramids on each end (fig. V1C). Zircon exhibits a wide range of morphologies, however, which can provide clues about the conditions of formation or the subsequent history of the grain (Pupin, 1980; Corfu and others, 2003). In igneous rocks, zircon is generally present as small, early formed crystals enclosed in later-formed minerals. In some cases, such as granite pegmatites and nepheline syenites, zircon forms large, well-developed crystals. Once zircon has crystallized, its refractory nature allows it to persist through repeated cycles of igneous activity, and inherited zircon is common in a variety of igneous rocks, either as complete grains or as internal cores of younger zircon crystals. In metamorphic rocks, zircon can form by recrystallization of existing grains or by growth of new material. At lower temperature and pressure, new zircon is rare, and metamorphic zircon is formed by partial to complete recrystallization of existing grains. Under more intense metamorphic conditions, new zircon forms more readily at subsolidus conditions and also during partial melting (Schaltegger and others, 1999; Rubatto and others, 1999). Rare authigenic zircon has been reported in sedimentary rocks (Saxena, 1966), but sedimentary zircon is derived primarily from the weathering of preexisting igneous, sedimentary, or metamorphic rocks. Detrital zircon (fig. V1D) in sediment and sedimentary rocks is highly durable and chemically inert and, therefore, can survive numerous cycles of reworking and concentration in the sedimentary environment.

Baddeleyite $\left(\mathrm{ZrO}_{2}\right)$ is a less common zirconium ore mineral that occurs in alkaline rocks, mafic and ultramafic rocks, and some metamorphosed carbonate rocks. It may occur with zircon and has been recognized as an accessory phase in a wide variety of rock types. Baddeleyite is most common in the late-stage, most chemically fractionated portions of mafic magmas (Heaman and LeCheminant, 1993), and it is the main zirconium-bearing phase in carbonatite rocks (fig. V $1 E$ ) because of the generally lower silica activity in carbonatite melts. As with zircon, the Zr:Hf ratio in baddeleyite can vary considerably, and baddeleyite has been shown to fractionate zirconium from hafnium, particularly in carbonatite systems (Scharer and others, 1997; Klemme and Meyer, 2003). In pristine mafic rocks, baddeleyite crystals are usually light tan to dark brown in color and form euhedral, wafer-thin blades that commonly contain striated crystal faces (Heaman and LeCheminant, 1993). Crystals are typically very small, often less than 30 microns in width (Söderlund and Johansson, 2002).

Eudialyte $\left(\mathrm{Na}_{15} \mathrm{Ca}_{6} \mathrm{Fe}_{3} \mathrm{Zr}_{3} \mathrm{Si}_{26} \mathrm{O}_{73}(\mathrm{OH})_{4} \mathrm{Cl}_{2}\right)$ is a relatively rare zirconium-bearing mineral that is locally abundant in some types of potassium- and sodium-rich rocks (Kogarko, 1990). It is an essential mineral in a variety of peralkaline nepheline syenites and nepheline syenite pegmatites, particularly those classified as agpaitic (Sørenson, 1997; Le Maitre, 2002). Eudialyte-bearing rocks have been identified in multiple alkalic intrusive complexes worldwide (Marks and others, 2011); the Lovozero Massif on the Kola Peninsula in Murmanskaya Oblast, Russia, hosts nearly monomineralic eudialyte ores that contain 10 percent $\mathrm{ZrO}_{2}$ (Kogarko, 1990).

Hafnon $\left((\mathrm{Hf}, \mathrm{Zr}) \mathrm{SiO}_{4}\right)$ is a rare hafnium-rich mineral that exhibits continuous solid solution with zircon. Synthetic hafnon has been produced with 100 percent hafnium substitution (Speer and Cooper, 1982), but naturally occurring hafnon crystals typically have $\mathrm{Zr}$ :Hf ratios of 0.03 to 0.08 . Hafnon occurs in tantalum-bearing granite pegmatites in the Zambézia district of Mozambique (Correia Neves and others, 1974), and hafnian zircon has been identified in a niobiumtantalum-rich granitic complex in China (Wang and others, 1996) and in several occurrences of granitic pegmatite worldwide (for example, Levinson and Borup, 1960; Černý and Siivola, 1980; Nickel and Robinson, 1985).

Zirconium and hafnium ore minerals are all primarily formed by crystallization from magma. The stability of zirconium- and hafnium-bearing phases in igneous systems is largely controlled by the concentration of the low-abundance 
elements (Watson and Harrison, 1984), so the element concentrations depend, in large part, on the magma source. Trace element patterns from basalts generated along mid-ocean ridges indicate that the upper mantle - the main source of melt generation beneath oceanic spreading centers - is relatively depleted in zirconium, hafnium, and other incompatible elements. Partial melting of the depleted upper mantle produces mainly tholeiitic or subalkaline basalts that have relatively low concentrations of zirconium and hafnium. In contrast, alkaline basalts formed in tectonic settings, such as oceanic islands and continental rifts, are relatively enriched in zirconium and hafnium because they are derived from deeper, more heterogeneous, undepleted, or locally enriched parts of the mantle (for example, Pearce and Norry, 1979; Fitton, 1987; Weaver and others, 1987). Mantle enrichment occurs through metasomatism; that is, through chemical alteration that results from interactions between rocks and fluid. This process can replenish lithophile elements in the mantle prior to melt extraction; however, the nature of mantle metasomatism and its role in the generation of alkaline basalts is still under debate (Bailey, 1987; Menzies, 1987; Hoffman, 1997).

Zirconium and hafnium concentrations in igneous systems are also a function of the processes of melt generation and liquid evolution. Alkaline magmas are derived from enriched or less depleted sources, but they also are formed from relatively low fractions of partial melt (Thompson and others, 1984; McKenzie, 1985). Small fractions of partial melt preferentially extract alkalis and other incompatible elements, thus concentrating these elements even more relative to the magma source. As a result, zirconium concentration in igneous rock suites derived from alkaline basalts is significantly greater than igneous rock suites derived from tholeiitic or subalkaline basalts (Engel and others, 1965). Zirconium and hafnium are further concentrated during crystallization of alkaline systems, as these elements tend to remain in the residual liquid because of their higher solubility in magmas rich in sodium, potassium, fluorine, chlorine, and hydroxide. In the Skaergaard intrusion of East Greenland, late-stage differentiates of the layered mafic-ultramafic complex have unusually strong enrichment of zirconium; that is, greater than $1,000 \mathrm{ppm}$. The enrichment is particularly significant because the initial magma concentration was $94 \mathrm{ppm}$, which is similar to the average zirconium content of tholeiitic or subalkaline basalts (Wager and Mitchell, 1951; Brooks, 1969).

Zirconium, hafnium, and other HFSEs are generally depleted in subduction zone magmas relative to mid-oceanridge, ocean-island, and rift-related basalts (Perfit and others, 1980). Rubatto and Hermann (2003) demonstrated that zircon is stable as a residual phase in subducted basalt and sediment and thus could limit the liberation of HFSEs into subduction zone fluids and melts. Melts generated in subduction zones are relatively rich in water, and the solubility of zirconium, hafnium, and other HFSEs in aqueous solutions is much lower than that for other incompatible elements, such as potassium (Gill, 1981, and references therein). As a result, some incompatible elements are scavenged and relatively enriched in subduction zone magmas, whereas others are more immobile and remain in the country rocks. As hydrous melts migrate through the mantle wedge, interaction with the depleted upper mantle leads to preferential HFSE depletion in the ascending magma (Kelemen and others, 1980). Less-depleted magmas in subduction zone systems may be produced if the melts interact with enriched pockets of lithospheric mantle beneath the crust (Edgar, 1987) or with metasomatized regions of the continental or oceanic crust. These effects are relatively localized, however, and the resulting concentrations of zirconium, hafnium, and associated HFSEs are still relatively low.

Because zirconium and hafnium are nearly identical in chemical properties, the geochemical behavior of hafnium during magma formation and differentiation is generally similar to that of zirconium. This is particularly true in mafic to intermediate magmas, which represent relatively pure silicate melts and have $\mathrm{Zr}$ :Hf ratios similar to the chondritic model of bulk silicate Earth composition (Bau, 1996; David and others, 2000). In other magmas, particularly highly evolved melts rich in boron, chlorine, fluorine, lithium, phosphorus, or water, $\mathrm{Zr}: \mathrm{Hf}$ ratios vary substantially and indicate decoupled fractionation of the two elements (Ellison and Hess, 1986). The general behavior of trace elements in highly evolved melts rich in volatiles is difficult to model quantitatively (Bau, 1996), and yet these are the kinds of magmas in which zirconium and hafnium are naturally concentrated. As a result, the hafnium content of the resulting ore minerals and (or) the presence of hafnon in igneous systems are variable and difficult to predict. In the Skaergaard intrusion, differentiation produced $\mathrm{Zr}: \mathrm{Hf}$ ratios that range from 59 in the most mafic portions to 85 in the most silica- and alkali-rich parts of the mafic-ultramafic complex (Brooks, 1970). In calc-alkaline suites, the Zr:Hf ratios of zircon range from 50 to 70 in gabbro to 30 to 35 in granite and suggest hafnium enrichment during magma evolution (Condie and Lo, 1971). Zircon from silica-undersaturated rocks, such as syenite and nepheline syenite, has low hafnium content and high Zr:Hf ratios relative to granite, whereas peralkaline granite, granitic pegmatite, and lithium-tantalum-bearing granite and pegmatite are the only rocks known to contain both hafnon (Correia Neves and others, 1974) and also zircon with high concentrations of hafnium (>30 percent) (von Knorring and Hornung, 1961; Wang and others, 1996) and also unusually low Zr:Hf ratios $(<20)$ (Wang and others, 1996).

\section{Deposit Types}

\section{Primary Igneous Deposits}

The world's largest primary deposits of zirconium and hafnium are associated with alkaline igneous rocks (Kogarko, 1990). These rocks also host much of the niobium, tantalum, and rare-earth elements (REEs) on Earth (Kogarko, 1990; Chakhmouradian and Wall, 2012), and they have a strong association with economic deposits of apatite (Kogarko, 1987; Singer, 1992) and diamond (Bergman, 1987; Dawson, 1987; 
Cox, 1992). Volumetrically, alkaline rocks account for less than 1 percent of all igneous rocks, however, and individual intrusions are typically of limited spatial extent and volume. Also, the concentration of zirconium and hafnium in these enriched igneous systems is still relatively low. Thus, only a few primary igneous deposits of zirconium- and hafniumbearing minerals are economic to mine at present.

The Kovdor deposit lies within the Paleozoic Kola alkaline province, which is located on the southwestern part of the Kola Peninsula in Murmanskaya Oblast, Russia (fig. V3). This deposit, from which baddeleyite is recovered as a byproduct of apatite and magnetite mining, is the only igneous deposit in the world that is currently producing zirconium (Singer, 1992). The Kovdor deposit is made up primarily of carbonatite and phoscorite; the carbonatites are represented by both calcite and dolomite carbonatite varieties. Phoscorites have carbonate mineral assemblages similar to those in the carbonatites but also include magnetite and silicate minerals, such as apatite, forsterite, and phlogopite (Rodionov and others, 2012). The ore complex (which covers a 0.8 -by-1.3-kilometer [km] area) is part of a 40 -squarekilometer $\left(\mathrm{km}^{2}\right)$ multiphase, concentric intrusion that also includes ultramafic rocks (clinopyroxenite and dunite) and nepheline syenite (Verhulst and others, 2000, and references therein). The intrusion extends down to $12 \mathrm{~km}$ with steeply dipping to vertical contacts (Arzamastsev and others, 2000), and it is surrounded by Archean biotite gneiss and granitic gneiss. The Kovdor intrusive complex was emplaced along the Kandalaksha Deep Fracture Zone, which is one of the most prominent structural features of the eastern Baltic Shield (Bell and others, 1996).

The broader Kola alkaline province consists of more than 24 intrusive complexes of Devonian age (380 to 360 megaannum [Ma]) (Kramm and others, 1993; Rodionov and others, 2012) that are exposed across more than $100,000 \mathrm{~km}^{2}$ from western Finland to the eastern part of the Kola Peninsula. Petrogenetic models for the Kola alkaline province suggest melt derivation from lithospheric mantle that was metasomatized prior to melting, and that the trigger for melting might have been a mantle plume (Sindern and others, 2004; Downes and others, 2005). Melt generation, migration, and emplacement were controlled by rifting perpendicular to and along regional northwest-southeast-trending structures with Precambrian ancestry (Dudkin and Mitrofanov, 1994). Associated intrusive complexes - namely the Lovozero and the Khibiny complexes - represent the largest agpaitic intrusions and contain the largest magmatic apatite deposits in the world (Kogarko, 1990). These intrusions also have localized phases that are enriched in zirconium, such as veins of pegmatitic nepheline syenite in the Khibiny complex that contain eudialyte. The Lovozero complex contains more widespread eudialyte-bearing nepheline syenite, called lujavrite, as well as ore horizons that contain up to 10 percent $\mathrm{ZrO}_{2}$ and between 50 and 90 percent eudialyte (Kogarko, 1990). Locally, lujavrite forms plate-like bodies up to 800 meters (m) thick. Despite the enrichment of eudialyte in both of these intrusions, neither Lovozero nor Khibiny is presently being mined for zirconium.

\section{Secondary Deposits-Coastal Placers and Paleoplacers}

Zirconium and hafnium ore minerals, particularly zircon, are present in a wide variety of rocks, but rarely in economic concentrations. Thus, most economic deposits are formed in sedimentary environments wherein zircon and other ore minerals are separated from their primary host rocks by weathering and erosion and transported and concentrated in surficial deposits. Zircon is chemically stable and hard (has a hardness of 7 on the Mohs scale) and is consequently quite durable in the sedimentary environment (Morton and Hallsworth, 1999). Zircon and other related ore minerals also have high densities and therefore accumulate under the influence of gravity in wind and water. The resulting heavy-mineral deposits, called placers, exhibit a wide range of physical characteristics, form in many different environments, and host a variety of minerals; for example, they are valuable resources for gold, iron, tin, and titanium (Slingerland and Smith, 1986; Garnett and Bassett, 2005). Alluvial placers form in rivers and streams, and they contain concentrations of zircon and other heavy minerals derived from source rocks within a drainage network. Additional concentration can take place as sediment moves downstream and as older river deposits are reworked by younger systems, although downstream dilution is more common.

In sediment deposited along the coasts, heavy-mineral enrichment takes place primarily in the foreshore and uppermost part of the shoreface environment (fig. V4D) where sediment is repeatedly reworked by wind, waves, and waveinduced currents. Coastal placer and paleoplacer systems, or beach placers, form along wave-dominated coastlines where reworking is most intense. They supply all of the world's current primary production of zircon and constitute the most important deposit type for zirconium and hafnium (Garnett and Bassett, 2005). Rigorously defined, a coastal placer is a concentration of heavy minerals within sediment deposited in a range of coastal sedimentary environments that are typically dominated by eolian, wave, and tidal processes (Hamilton, 1995). The concentrating agent at the site of deposition is primarily mechanical, and the presence and concentration of zircon and other economically important minerals, such as ilmenite and rutile (for titanium), chromite (for chromium), and monazite (for REEs) are dependent on a variety of factors described below. Most deposits range in age from the Eocene Epoch to the present, and economically viable deposits occur along numerous modern beaches on nearly every continent (fig. V3; for example, Peterson and others, 1986; Mallik and others, 1987; Hamilton, 1995; MacDonald and Rozendaal, 1995; Hou and others, 2011). Rare examples of much older paleoplacers, such as the Archean Witwatersrand deposit in South Africa, have been successfully mined, although primarily for gold (Minter, 2006). 


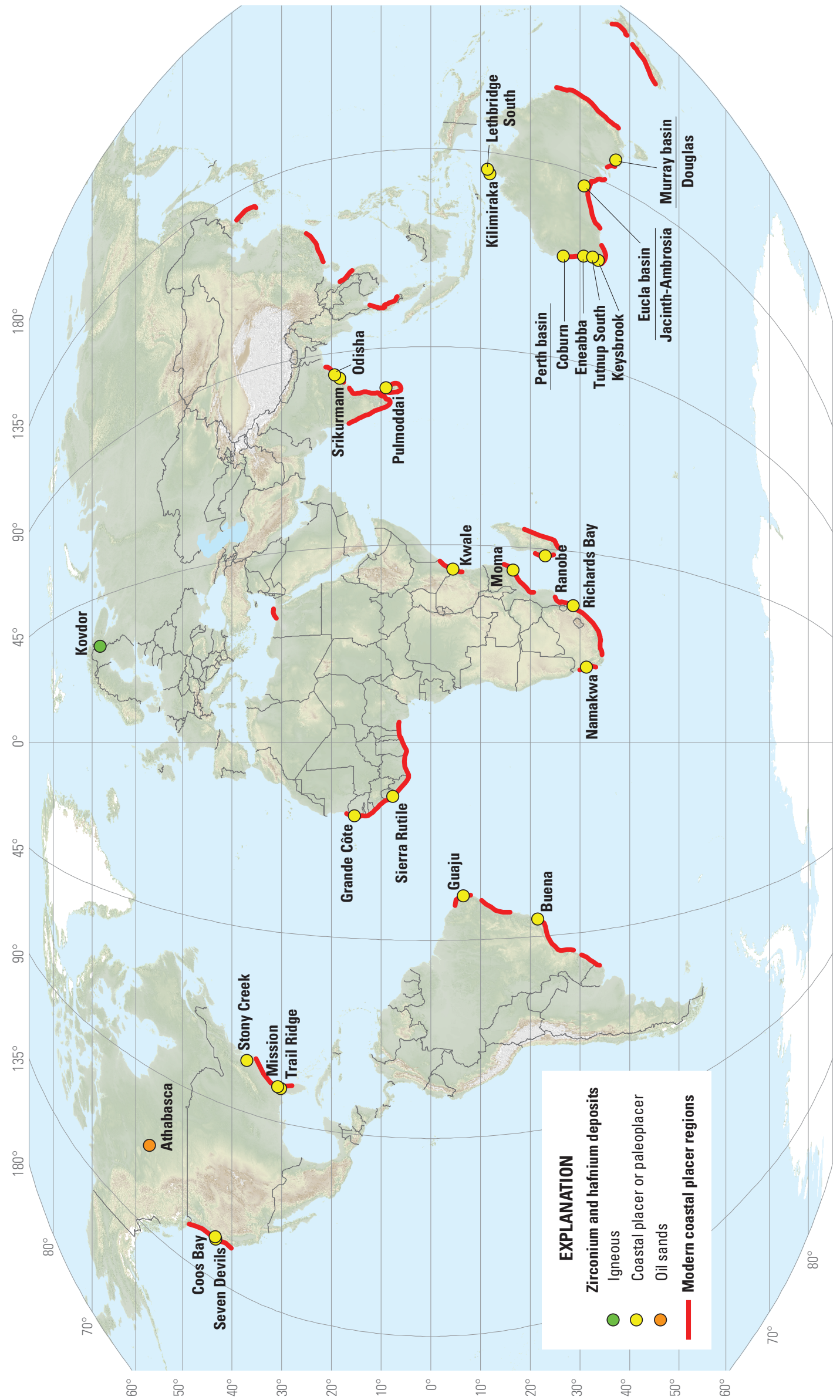

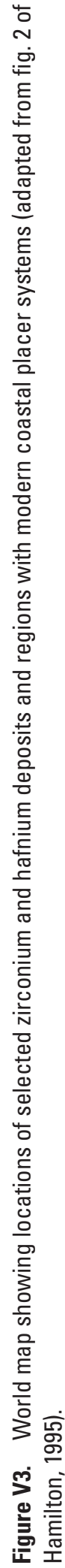


Coastal placers are typically fed by detritus derived from deeply weathered bedrock source terranes that include abundant felsic to intermediate crystalline rocks (fig. V4A). Host sands form coast-parallel surficial bodies, such as barrier islands (figs. V $4 B$ and $\mathrm{V} 4 C$ ), and older sand bodies form topographic highs inland of the modern coastline that represent former barrier islands or eolian dunes (fig. V4A; Force and Rich, 1989). Sand bodies are formed in the foreshore, shoreface, dune, tidal delta, and washover environments (figs. V4B and V4D; Roy and others, 1994); the economic heavy-mineral concentrations within these systems are typically about $10 \mathrm{~m}$ thick, $1 \mathrm{~km}$ wide, and more than $5 \mathrm{~km}$ long. In some cases, economic deposits are made up of amalgamated smaller sand bodies of similar origins or superimposed composite bodies from different environments (Force, 1991). The mineral grains in most economic deposits are medium- to fine-grained sand-sized, well sorted, generally well rounded, and typically unindurated (fig. V1G). Welldeveloped weathering profiles are superimposed on most sand bodies, and local cementation by iron oxides, clay minerals, or humate is common. The proportions of heavy minerals vary considerably both within deposits and among sand bodies (fig. V1F); the average concentration of total heavy minerals in economic deposits ranges from less than 1 percent to about 25 percent. Zircon makes up a relatively small percentage of the economic heavy minerals in most deposits; thus, zircon is primarily a byproduct of heavy-mineral sand mining for the titanium minerals ilmenite and rutile.

In a review of some of the world's major coastal titanium- and zirconium-placer-forming regions, Hamilton (1995) noted the following three major factors that were common to all of them: (a) placer-forming regions lie on a trailing continental margin (Inman and Nordstrom, 1971), (b) margins are bounded by escarpments, and (c) heavy minerals were derived from Precambrian metamorphic bedrock regions and intermediate sedimentary hosts. Otherwise, individual deposits vary considerably in terms of their structure, location, and conditions of formation. Hamilton (1995) examined the controls on placer formation that act at different spatial and temporal scales and developed a conceptual model focused on the genetic characteristics of the placer-forming regions. The conceptual model is shown as a flow chart in figure V $5 \mathrm{~A}$, with broader controls, such as the tectonic setting and bedrock geology of a region, at the top and more localized controls, such as coastal plain morphology and coastal physiography, at the bottom. The shading and hatched patterns indicate the time scales at which the different controls occur, and the arrows indicate potential interactions between different controls within the placer-forming system. The rest of this section discusses some of these key controls and how they influence placer formation.

The most important long-term control on placer formation is tectonic setting. In general, major placer-forming regions form on passive margins, as illustrated by modern coastal placer regions on passive tectonic margins, such as the eastern coast of North America and South America and the western and southeastern coasts of Africa (fig. V3). Coastal placers can also form along both convergent and transform margins, as evidenced by placers along the Oregon coast (Coos Bay, Seven Devils Mine) (Peterson and others, 1986) and both the main islands of New Zealand (Brathwaite and Christie, 2006). The size of these deposits is small compared with those in some other regions, such as southern Australia and South Africa, however. Most major placer-forming regions overlie broad coastal plains of Mesozoic sediments, and all have an escarpment that separates the low-lying coastal plain from the hinterland, or the broad inland region behind the coastal plain that includes the piedmont and more distal regions of basement bedrock outcrops (fig. V4A). Escarpments are relatively dynamic features that act over intermediate time scales, and they are important because they (a) provide a mechanism for initiating erosion of bedrock through headwall retreat, (b) provide a mechanism to rejuvenate fluvial landscapes and evacuate stream valleys during periods of low sea level, thus providing sediment to the outer edge of the coastal plain for subsequent reworking and enrichment, (c) provide a distinct landward barrier to marine transgression that restricts the location of repeated reworking of coastal sediments during periods of rapid sea-level change, and (d) indicate tectonic instability or flexure along the margin that can elevate and preserve heavy-mineral concentrations near the escarpment (Hamilton, 1995).

The lithology of the hinterland region is the most variable aspect of the tectonic setting of major placer-forming regions. Most placers are adjacent to provinces underlain by Precambrian crystalline bedrock, whereas others were derived from basaltic terranes or Phanerozoic orogenic belts. Thus, Hamilton (1995) points out that, although lithology is an important control on the presence and abundance of economic minerals, there are other key influences on the degree of concentration and, therefore, the economic potential of placers and paleoplacers. The weathering history of the source region is perhaps most important in determining the likelihood of concentration of a suitable mineral suite. The most enriched modern placer systems are located at latitudes lower than $35^{\circ}$ (fig. V3; Force, 1991). Climatic change during the Cenozoic Era played an important role in the development of paleoplacer deposits worldwide directly through more intense weathering and, more indirectly, through repeated cycles of sea-level change (Force, 1991). Many of the major placer coastlines of the world underwent a shift from arid to tropical conditions during the Quaternary Period. This longer term trend, coupled with more rapid and repeated shifts in climate, produced large volumes of regolith in source areas, preferentially removed unstable minerals from existing coastal placers, and led to alternating periods of high and low sediment delivery to the coast. Repeated sea-level change associated with glacial-interglacial cycles caused multiple marine excursions across the continental margins, leading to extensive sediment reworking, heavy-mineral enrichment, and preservation of strandlines associated with sea-level highstands (fig. V4A). These processes were most significant 


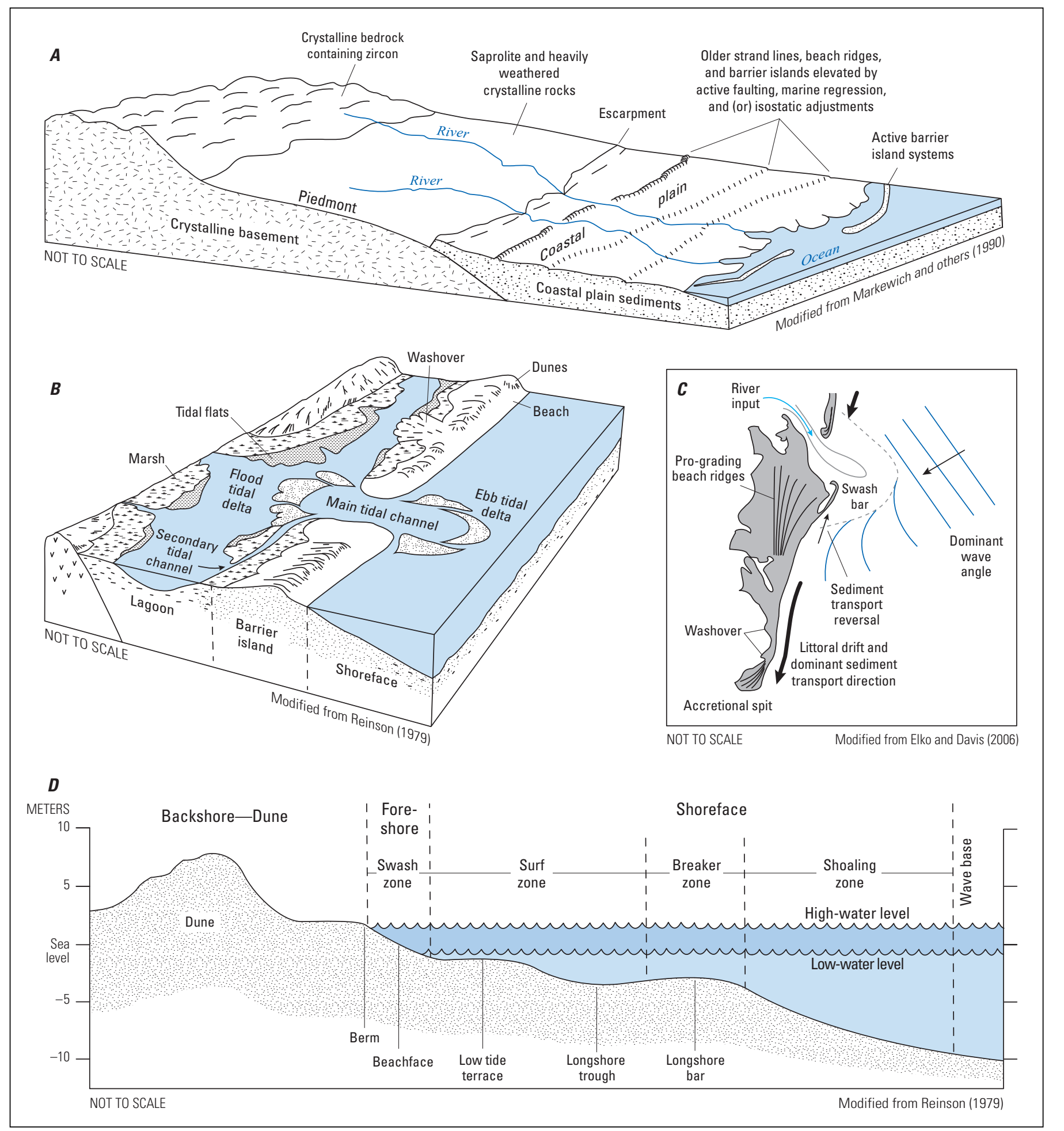

Figure V4. Examples of coastal depositional systems with an emphasis on barrier island location, morphology, and depositional environments. $A$, Schematic model for coastal placer systems. Zircon is derived from deeply weathered crystalline bedrock, delivered to the coast by river systems, and concentrated by a variety of factors, including wind and waves, storm events, tidal action, and ocean currents. Zircon may also be derived from older coastal plain sediment or offshore sediment. $B$, Depositional environments associated with barrier island systems. The highest concentration of zircon and other heavy minerals are found primarily in the beach, dune, and washover environments. $C$, Process-response model and features of a drumstick barrier island system along coasts, such as that of the Southeastern United States, that have a consistent supply of sediment from major rivers. Sediment is redistributed from river input in the direction of littoral drift (bold arrows), and heavy-mineral concentration occurs in the beach and washover environments. $D$, Generalized profile of barrier beach and shoreface environments. 
Figure V5. Influences on and locations of placer formation in coastal environments. $A$, Conceptual model showing influences on placer formation in coastal environments. Influences of the different components of the coastal system are indicated by arrows, and relative time scales for variability of select components are indicated by shading and diagonal lines. $B$ and $C$, Models for enrichment of heavy minerals in the coastal environment by $(B)$ littoral drift and $(C)$ washover in transgressive barriers. $D$, Schematic cross-section through an idealized barrier island complex showing four different types of heavy-mineral deposits and their association with host barrier environments: (1) lag deposits, which are formed along erosional discontinuities or surfaces between barrier islands of different ages; (2) transgressive deposits, which are formed at the rear of barrier islands immediately landward of the strand plain during periods of rising sea level; (3) regressive deposits, which are formed in barrier islands that have a consistent supply of sediment during periods of falling sea level; and (4) eolian dune deposits with relatively low-grade disseminated heavy-mineral deposits formed downwind from heavy-mineral-rich beaches.


Modified from Roy and others (2000)
Modified from Roy and others (2000)

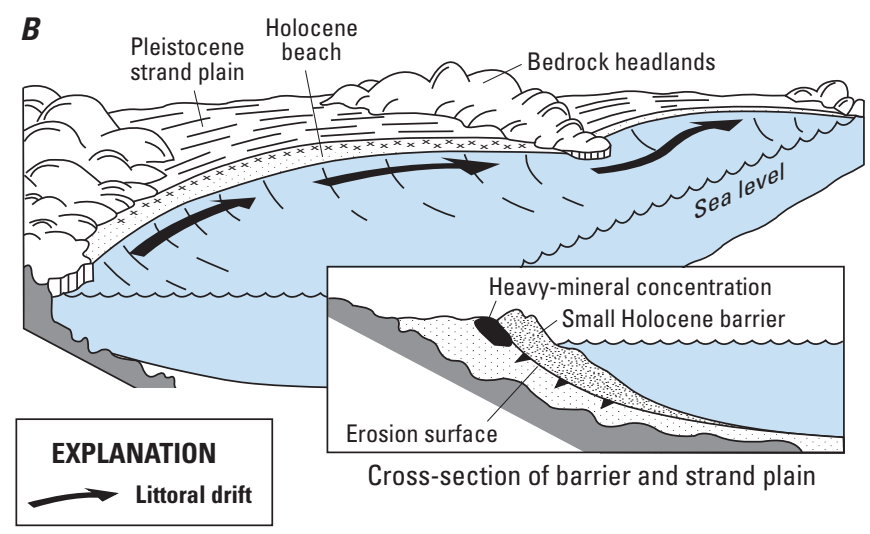

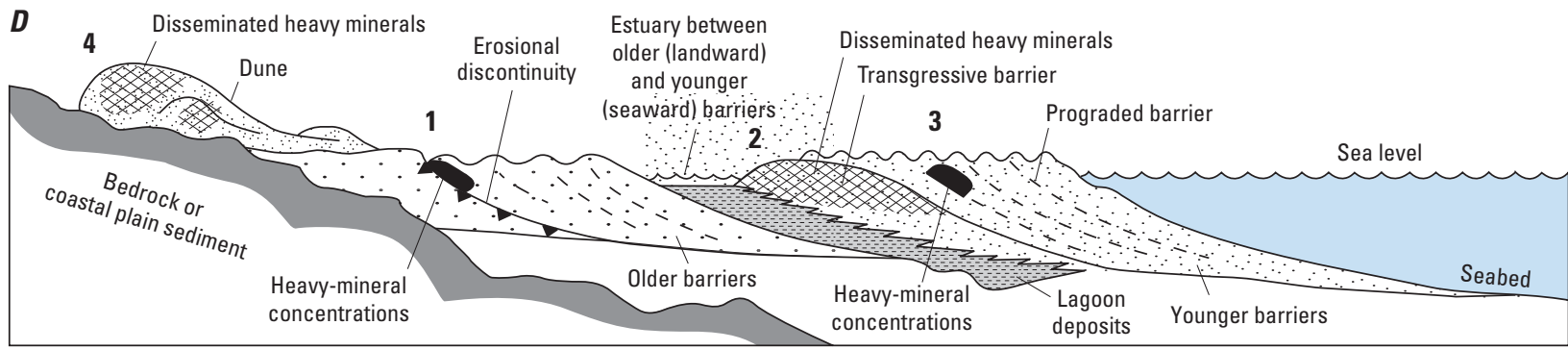

NOT TO SCALE 
for placers lying near the coast during the Quaternary Period, but similar processes have also been cited as important in Eocene to Pliocene deposits as well (Puffer and Cousminer, 1982; Carpenter and Carpenter, 1991; Hou and others, 2011).

Factors that vary over short-term, quasi-instantaneous time periods include tides, storms, winds, and waves. Microtidal coasts - that is, those with tidal ranges of less than $2 \mathrm{~m}$, such as those in southwestern Australia-have long been considered to be the most favorable for coastal placer development (Sutherland, 1985). In these systems, placers of beach (foreshore environment) and eolian (backshore or dune environment) origin are common (figs. V4B and V4D; for example, Hou and others, 2011). In mesotidal ( 2 to $4 \mathrm{~m}$ ) to macrotidal ( $>4 \mathrm{~m}$ ) systems, such as those of the Southeastern United States and eastern India, placers are more likely to be found in finer grained progradational beach-ridge systems associated with river mouths (fig. V4C; for example, Pirkle and others, 1984). Storms, winds, and waves can have more variable effects on coastal morphology and placer development. Storm events can significantly modify coastal geomorphology, and storm surges can erode offshore sand deposits along the continental shelf and produce substantial heavy-mineral enrichment in the shoreface and washover environments (figs. V4B and V4D; Leatherman and others, 1977; Roy, 1999; Roy and others, 2000; Buynevich and others, 2004). Strong onshore winds winnow shoreface deposits at low tide and ultimately transport sediment inland from the beach or foreshore environment, trapping deposits in the backshore environment well above sea level (figs. V4D and V5D; Roy, 1999). Economically important dune deposits formed by strong onshore winds are found in all regions except South Africa, where longshore winds are more significant for placer formation (MacDonald and Rozendaal, 1995). Trail Ridge, which is a prominent physiographic feature that extends for more than $160 \mathrm{~km}$ across Florida and Georgia, formed as a coast-parallel dune complex during a major Pleistocene sea-level highstand and has been an important domestic source of titanium minerals and zircon production since 1949 (fig. V3; Force and Rich, 1989).

Waves and ocean currents are perhaps the most important agents in producing economic heavy-mineral sand deposits. In areas such as southeastern Australia, where sands are not derived directly from rivers, waves drive large sand fluxes onshore and in longshore transport currents that move the sand along the coast from south to north in a process known as littoral drift (figs. V5B, and V5C; Roy, 1999). Prominent bedrock headlands along the drift-aligned coastlines trap heavy minerals on the up-drift side of embayments, and enrichment takes place along erosional surfaces between different-aged barriers (fig. V5B; Roy, 1999). Similar processes have been described in beach placers along the Oregon coast, where reversing seasonal currents serve to both winnow and subsequently preserve heavymineral sands in pockets adjacent to the headland (Komar and Wang, 1984; Peterson and others, 1986, 1987).
In areas with more consistent sediment supply from external sources, such as inland river systems or scouring of the sea bed, heavy minerals are concentrated in sand-rich barrier-island systems (figs. V4A and V4B). Reworking and concentration takes place primarily in the upper shoreface environment in the beach and washover environments, and heavy-mineral-rich sands are distributed and further fractionated during transport along the length of the barriers by littoral drift (figs. V4C and V5C; Roy, 1999). Many economic deposits in the Florida and Georgia coastal plain of the Southeastern United States occur where Pleistocene and Holocene beach ridges intersect ancestral to modern river systems, thus illustrating the importance of rivers as a source of heavy minerals in this particular coastal system (Hails and Hoyt, 1972; Pirkle and others, 1974, 1984). The deposits extend in the direction of littoral drift (south) for kilometers from the river intersection and help to define a series of long linear ridges that represent relict shorelines formed during a succession of marine transgressions from the Pleistocene Epoch to the present (Winker and Howard, 1977). Economic deposits occur locally in modern barrier islands adjacent to river mouths along the Florida and Georgia coasts, and some of these have been mined in the past (Pirkle and others, 2007).

Other factors may also exert local control over placer formation and distribution. These include tectonic effects, such as active faulting (Peterson and others, 1987; Roy and others, 2000), flexure (Cronin and others, 1984), or isostatic uplift (Opdyke and others, 1984) that might increase sediment supply, promote reworking, or enhance the potential for preservation. These effects, however, must be analyzed in the context of the other variables described above to adequately assess the prospectivity of a particular deposit or region.

\section{Resources and Production}

\section{Identified Resources}

World zircon reserves are estimated to be 78 million metric tons of contained zirconium oxide $\left(\mathrm{ZrO}_{2}\right)$ (Bedinger, 2015b). Domestic zirconium reserves are estimated to be 500,000 metric tons of $\mathrm{ZrO}_{2}$, and estimated resources include approximately 14 million metric tons of zircon associated with titanium resources in heavy-mineral sand deposits (Bedinger, 2015b).

Zircon production in the United States is a byproduct of mining and processing heavy-mineral sands for titanium minerals in Florida and Virginia. U.S. companies usually consider data on domestic production and consumption of zircon concentrates to be proprietary and generally withhold these data. U.S. exports of zirconium ore and concentrates generally declined from 2005 to 2011 (fig. V2C), and the United States was a net importer of zirconium ore and concentrate in 2011 for the first time since 1998 (Gambogi, 2012a). The United States is one of the leading world producers of zirconium and hafnium metal, along with France and Russia (Gambogi, 2012a). 
New heavy-mineral sand mines have been brought online in Kenya, Senegal, and South Africa in recent years. The Kwale project in Kenya began production in 2014 and was expected to produce 30,000 metric tons per year over a 60 -year mine life. The Tormin project in South Africa was expected to produce 48,000 metric tons per year of nonmagnetic concentrate grading 81 percent zircon and 11.6 percent rutile over a 4-year mine life. In Senegal, the Grand Côte project was expected to produce 85,000 metric tons per year during a mine life of 20 years. In the United States, a new zircon mine started up in southeastern Georgia in 2014, and a second mine was expected to begin production in late 2015 (Bedinger, 2015b).

\section{Other Resources}

Because of its relative ubiquity in crustal rocks and its high specific gravity, zircon is likely present in most if not all placer deposits, but it is not always recovered during placer mining. Placers and paleoplacers have been mined since humans first used metals (Garnett and Bassett, 2005), but the first economic extraction of zircon took place only in the first half of the 20th century (Elsner, 2010). Global zircon production has historically been a byproduct of titanium mineral extraction, and, thus, potentially significant economic concentrations of zircon might remain in tailings processed exclusively for titanium and other commodities, such as gold, iron, REEs, and tin. In KwaZulu, Natal, South Africa, a mine tailings treatment plant was commissioned at Richards Bay (fig. V3) to recover heavy-mineral concentrates, including zircon, from approximately 30 years of accumulated mine tailings initially processed primarily for titanium minerals (Gambogi, 2012a). Similar treatment plants are in development to recover titanium minerals and zircon from tailings of the Athabasca oil sands project in the Province of Alberta, Canada (fig. V3). Depending on future price fluctuations, economic concentrations of zirconium and hafnium ore minerals might also be recovered from tailings of primary igneous deposits, particularly in alkaline igneous provinces, such as in central Arkansas (Flohr and Ross, 1990). These two examples highlight the potential for recoverable resources from tailings in a wide variety of settings where zircon is not or was not the primary commodity of interest in the past but may be present at economic concentrations and is also relatively easy to extract.

In addition, older, lithified sedimentary units sourced from more fertile bedrock regions (Dickinson, 2008) could yield economic concentrations of zircon, especially in areas where the bedrock was deeply weathered. One such example is the Cretaceous Tokio Formation that is exposed in southwestern Arkansas, which contains ilmenite-bearing sands derived in part from deeply weathered alkaline intrusions in the surrounding area (Hanson, 1997). Zircon could be recovered during quarrying operations for sand, gravel, and aggregate in environments or regions where relatively fertile bedrock might be exposed (for example, continental rift systems or uplifts of crystalline bedrock) or where surficial heavy-mineral concentrations might exist (for example, river valleys, dunes, or high-energy coastal deposits).

\section{Exploration for New Deposits}

The process of identifying and evaluating heavy-mineral sand deposits requires careful consideration and assessment of the many variables outlined above. Exploration of modern to recent coastal placer systems is aided by the relative ease of identifying the coastal morphology and physiography, sediment supply and distribution systems, geologic setting, and climate history. Identifying and understanding the distribution, geometry, and evolution of paleoshorelines is more difficult because of the complex interactions between medium- to short-term factors and increased potential for reworking and burial. One notable example - the discovery and development of the Ambrosia and Jacinth heavy-mineral sand deposits in the Eucla basin of southern Australia (fig. V3; Hou and others, 2011) - provides a possible template for exploration. The Eucla basin initially was recognized as an extensive area of preserved Cenozoic marine sediment spanning approximately 50 million years (m.y.) of deposition with a high degree of preservation and high prospectivity for heavy-mineral deposits (Clarke and others, 2003, and references therein); however, early exploration revealed a need to better understand the geometry and evolution of the paleoshorelines to provide a focus for exploration. The reconstruction of complex sequences of coastal deposition constrained by a detailed chronology of major sea-level events (McGowran and others, 1997) and models for heavy-mineral concentration (Roy, 1999; Roy and others, 2000) led to successful prediction of new prospective sites and key discoveries (Hou and others, 2011). Mining at the Jacinth deposit was commissioned in 2009 , and more than 12 separate heavy-mineral prospects where zircon is the dominant component of the heavy-mineral assemblage have been identified (Hou and others, 2011). The Eucla basin represents an important new region of heavymineral sand resources; deposits in the region are capable of producing approximately 300,000 metric tons of zircon in their initial years of production.

Other regions with long records of Cenozoic coastal deposition remain the most prospective worldwide. Similar to the Eucla basin in Australia, the Gulf of Mexico Basin in the southern United States records more than 60 m.y. of sediment deposition and coastline evolution. Sufficient outcrop, seismic, and borehole data have been collected to describe the extent of various sedimentary facies associated with numerous depositional episodes in the Gulf of Mexico Basin. The basin includes volumetrically significant Paleocene through Miocene coastal plain and shore zone facies deposits (Galloway and others, 2000). The Gulf of Mexico Basin has been extensively evaluated for petroleum resources, but units representing paleoshorelines have not been thoroughly studied for the occurrence of heavy-mineral resources. 


\section{Environmental Considerations}

\section{Sources and Fate in the Environment}

The behaviors of zirconium and hafnium in the environment are very similar to one another-most notably, that zirconium- and hafnium-bearing minerals have limited solubility and reactivity in the environment. More literature is available on the behavior of zirconium than of hafnium, but the studies on zirconium are generally applicable to hafnium for the following reasons: the elements are extremely similar chemically (that is, they have almost identical atomic sizes and analogous electronic structures); they nearly always occur together; hafnium occurs in solid solution with zirconium in zircon; and hafnium is recovered as a byproduct during zirconium extraction. Anthropogenic sources of zirconium, and likely those of hafnium, are from industrial zirconiumcontaining byproducts and emissions from the processing of sponge zirconium; exposure to the general population from these elements is generally considered small (Schaller, 2004).

The concentrations of zirconium in soils, waters, and the air are significantly higher than those of hafnium because of the higher crustal abundance of zirconium. The mean concentration in soils worldwide is $300 \mathrm{ppm}$ (or 300 milligrams per kilogram [mg/kg]; the range is from 30 to $2,500 \mathrm{ppm}$ ) for zirconium compared with a mean concentration of $3 \mathrm{ppm}$ (and a range of from 2 to $20 \mathrm{ppm}$ ) for hafnium (KabataPendias and Mukherjee, 2007). According to Shacklette and Boerngen (1984), soils in the conterminous United States have zirconium concentrations that average $230 \mathrm{ppm}$ and range from less than 20 to 2,000 ppm; hafnium concentrations were not reported (Shacklette and Boerngen, 1984). According to Govindaraju (1994), reference soils from the United States contain between 2.5 to $17 \mathrm{ppm}$ hafnium, and average $7.3 \mathrm{ppm}$. The ratio of zirconium to hafnium concentrations in waters is usually similar to their ratio in soils, but their concentrations are commonly very low because they are relatively immobile compared with some other elements (Gaillardet and others, 2003). Concentrations of less than 1 part per billion (ppb) (or 1 microgram per liter) for zirconium are common for natural waters, and concentrations for hafnium are typically less by an order of magnitude. According to Reimann and de Caritat (1998), the median dissolved and total concentrations in stream waters worldwide range from 0.01 to $0.9 \mathrm{ppb}$ for zirconium and from 0.009 to $0.03 \mathrm{ppb}$ for hafnium. Gaillardet and others (2003) reported average global dissolved concentrations in rivers of $0.04 \mathrm{ppb}$ for zirconium and $0.006 \mathrm{ppb}$ for hafnium. Industrial emissions likely do not increase these concentrations significantly (Schaller, 2004). Zirconium and hafnium are found in higher proportions in sediment in rivers than in the dissolved fraction. Globally, the average concentration in suspended sediments in rivers is $160 \mathrm{ppm}$ for zirconium and $4.4 \mathrm{ppm}$ for hafnium (Viers and others, 2009). In the atmosphere, zirconium concentrations for industrial regions range from 0.2 to 7 parts per trillion (ppt) (or 0.7 to 26 nanograms per cubic meter $\left[\mathrm{ng} / \mathrm{m}^{3}\right]$ ) for zirconium and reach more than
$0.09 \mathrm{ppt}\left(0.32 \mathrm{ng} / \mathrm{m}^{3}\right)$ for hafnium (Reimann and de Caritat, 1998; Kabata-Pendias and Mukherjee, 2007).

Little reported information is available on the pre-mining geochemical signatures of soils, sediment, and waters around heavy-mineral sand deposits and around the carbonatite deposit in Russia that is currently being mined for zirconium and hafnium. In general, carbonatites, soils, stream sediments, and weathered rock may be enriched in iron, niobium, phosphorus, REEs, thorium, and uranium before mining (Modreski and others, 1995); if baddeleyite is present, zirconium and hafnium may also be enriched. Because most of these elements (that is, hafnium, niobium, REEs, thorium, uranium, and zirconium) occur in relatively stable insoluble minerals, the stream water and groundwater around the deposits may not display the same geochemical signature as the soils and stream sediments (Modreski and others, 1995).

Only small amounts of zirconium and hafnium are recycled. Less than 1 percent of discarded zirconium and hafnium metal or alloy is recycled or reused worldwide, and the recycled content of zirconium in products globally is only between 1 and 10 percent; estimates were not available for hafnium (Graedel and others, 2011). The recycled content includes both new (loss during manufacturing products that is transferred to the scrap market) and old (post-consumer) scrap (Graedel and others, 2011). Most of the zirconium recycled is from scrap generated during metal production and fabrication, and hafnium metal recycling is insignificant (Loferski, 2013b). The low proportions of these minerals that are recycled may be a reflection of the complex materials, such as electronic equipment, that they are used in; the technical difficulty of recycling them; and the small amounts used in these products. Also, the long lifetime of some products in which zirconium and hafnium are used make the minerals' return to production very slow. One recent research study suggests a new method for economically recovering and recycling zirconium from used nuclear fuel cladding (Collins and others, 2011).

\section{Mine Waste Characteristics}

The volume and characteristics of mine waste produced from the recovery of zirconium and hafnium depend on the deposit type exploited and its size. Currently, the most important deposits for zirconium and hafnium are heavymineral sands and carbonatites.

\section{Volume of Mine Waste}

Processing heavy-mineral sands at a mine site produces waste material that includes tailings and slimes. Mechanical separation produces quartz-rich tailings after the heavy minerals are separated out. During wet concentration, slimes, which consist of a slurry of fine-grained materials (commonly clay minerals) are separated from the quartz and heavy minerals and mixed with a flocculent to cause settlement of the clay minerals and other clay-sized particles. 
The percentages of heavy minerals and clay minerals in a deposit are variable and consequently result in various amounts of the different types of waste. Generally, heavy minerals make up from 1 to 25 percent of the material in economic deposits but additional natural sorting can concentrate them further. Zircon is only a small fraction of the total heavy-mineral content of a deposit. Heavy-mineral sand deposits in Western Australia, two deposits in India (Sattankulam and Kuttam), and one deposit in southeastern Virginia (Old Hickory) contain up to 10 percent heavy minerals (Murty and others, 2007; Zimmerman and others, 2008). In contrast, heavy-mineral sands on the northeast coast of Sri Lanka (the Pulmoddai deposit) are very high grade and contain up to 80 percent heavy minerals, including ilmenite (70 percent), zircon ( 8 to 10 percent), rutile ( 8 percent $)$, sillimanite ( 1 percent $)$ and monazite $(0.3$ percent $)$; approximately 2 percent of the sand is clay sized (Premaratne and Rowson, 2003). Approximately 15 percent, by volume, of the two heavy-mineral sands deposits in India is clay sized and would be separated out and disposed of as slime (Murty and others, 2007). The measured reserves of these two deposits are estimated to be 400 million metric tons of raw sand that covers approximately $120 \mathrm{~km}^{2}$ (Murty and others, 2007). The amount of waste generated by these two deposits would be much greater than for the smaller $\left(3.2 \mathrm{~km}^{2}\right)$ but higher grade deposit in Sri Lanka (Premaratne and Rowson, 2003). For another comparison, up to $50 \mathrm{~km}^{2}$ of land could potentially be mined for heavy minerals $\mathrm{d}$ in the coastal plain region of the Southeastern United States (Daniels and others, 2003). The modern mining of these deposits, along with many other heavy-mineral sand deposits worldwide, commonly involves removing the organic soil layer (if present), mining the sands, and then backfilling with tailings and slimes and replacing the organic soil layer. For operations that restore the landscape to pre-mining conditions, the volume of waste and its impact on the landscape is generally only a temporary land-use issue.

A variety of types of mine waste have been produced at the Kovdor Mine in Murmanskaya Oblast, Russia, which is the only carbonatite deposit from which zirconium and hafnium are currently being recovered. The Kovdor carbonatite complex in Russia has been mined for a variety of ores that include apatite-baddeleyite-magnetite, phlogopite, and vermiculite, and estimating the large expanses of mine waste within the complex is challenging. One report by the Kola Science Center of the Russian Academy of Sciences (1999) reported volume estimates for waste produced before the end of 1994. The amount of overburden rock stripped and stored at the mine site was estimated to be more than 700 million metric tons; a small fraction of the overburden was used for construction purposes. In addition to overburden, mine waste included more than 61 million metric tons of low-iron-content rock and approximately 10 million metric tons of apatite-staffelitebearing rock. (Staffelite is carbonate-rich fluorapatite.) The site contained a total of nearly 200 million metric tons of tailings, including 64 million metric tons from the processing of magnetite ore that was available for recovery of apatite and baddeleyite. As of 1994, 6 million metric tons of tailings had already been processed to recover apatite, baddeleyite, and magnetite (Russian Academy of Sciences, 1999).

\section{Mineralogy and Chemistry of Slimes and Tailings}

The mineralogy and chemistry of the slimes and tailings produced at heavy-mineral sand mines worldwide have many similarities; however, differences in the proportions of some minerals result in some variations. For example, slimes from the mineral-sand deposits in India contain mostly hematite, kaolinite, and quartz (Murty and others, 2007), whereas slimes from the Yoganup North Mine in Western Australia contain predominantly kaolinite ( 80 percent) and lesser amounts of quartz (10 percent) and goethite (10 percent) (Fujiyasu and others, 2000). Another example is the heavy-mineral sand deposit on the northeast coast of Sri Lanka, where the separation process for the concentrate generates a low-density fraction ( 24 percent) of quartz-rich tailings, a nonmagnetic heavy fraction (21 percent) that contains rutile and zircon, and a magnetic heavy fraction (55 percent) of mostly ilmenite and pseudorutile (Premaratne and Rowson, 2003).

Several studies have been conducted that characterize the composition of waste dumps in various stages of reclamation (that is, of reclamation pits) at heavy-mineral sand processing sites in Florida and Virginia (Daniels and others, 1992, 2003; Orndorff and others, 2005). In 2007, the deposit at the Old Hickory Mine in Virginia contained an average of 7 percent heavy minerals and an average of 35 percent clay minerals (the range of clay minerals was from 5 to 50 percent) (Zimmerman and others, 2008); the heavy minerals found at this mine were very similar to those contained in the nearby Brink and Concord deposits and included ilmenite, leucoxene, rutile, and zircon. One study examined soil profiles from within the reclamation pits at the Old Hickory Mine (these materials are referred to as "soils" despite being altered by mining). The reclamation pit soils were mixed slimes and tailings deposited as a slurry and left to dewater; then, soil amendments, including biosolids, fertilizer, and lime, were added. The slimes, which were composed mostly of kaolinite and lesser amounts of other clay minerals (vermiculite and smectites), were shown to separate from the quartz-rich tailings in the pits, which leads to lateral and vertical variability within the pits. The surface horizon (that is, the upper 10 to 24 centimeters) in the pits, most of which had been amended with biosolids and lime, had near neutral $\mathrm{pH}$ values and contained up to 1.5 percent organic matter. In contrast, samples collected from below the surface material were generally acidic and contained little organic matter (Orndorff and others, 2005). Extractable concentrations of several elements, including phosphorus $(<100 \mathrm{ppm})$, magnesium $(<300 \mathrm{ppm})$, potassium $(<400 \mathrm{ppm})$, and calcium $(<3,000 \mathrm{ppm})$, were generally low in both surface and subsurface samples, despite fertilizer and lime additions (Daniels and others, 2003). Although no obvious deficiency symptoms were noted in 
vegetation growing on the pits, the acid extractable amounts of some micronutrients, such as copper $(<2 \mathrm{ppm})$, zinc $(<6 \mathrm{ppm})$, and boron $(<1 \mathrm{ppm})$ were low (Daniels and others, 2003). Another study (Daniels and others, 1992) examined mine soils from the Green Cove Springs Mine in Florida. The reclamation pit soils there are similar to those at the Old Hickory Mine in that the amended surface layers are more organic-rich than the subsurface samples; in contrast to the Virginia sites, however, very little clay material was found in the Florida deposit (Daniels and others, 1992). Both the natural and mine soils in the subsurface are acidic at the site in Florida.

The composition of mine waste produced from the recovery of baddeleyite from igneous deposits is very different from that produced from the recovery of zircon from heavy-mineral sand deposits. At the Kovdor deposit in Russia, baddeleyite is recovered as a byproduct of apatite and magnetite mining. Currently, the minerals are recovered from the ore in three sequential steps that begin with separating out the magnetite by magnetic concentration. The tailings from this first step are then processed by flotation to recover apatite and, finally, the post-apatite tailings are used to recover baddeleyite. According to Petrov (2004), the final tailings at the Kovdor Mine consist almost entirely of calcite and forsterite. Tailings produced before the recovery of apatite (recovery began in 1975) and baddeleyite (recovery began in 1977) are currently being reprocessed to recover these minerals. Kononov and others (1992) reported that these tailings contain the following: forsterite (50 to 60 weight percent), carbonates (20 to 25 weight percent), apatite ( 5 to 10 weight percent), and baddeleyite $(<0.15$ weight percent). Similarly, Zosin and others (2011) reported that the mineralogy of the tailings currently being produced at the site is dominated by apatite, carbonates, and forsterite (greater than 25 weight percent each), along with some phlogopite (approximately 12 weight percent), and lesser amounts of diopside and magnetite. In addition to tailings, overburden is an additional waste product and contains mostly pyroxene and amphibole (approximately 40 weight percent combined total), carbonate (approximately 20 weight percent), and minor amounts of apatite, forsterite, mica, and other minor minerals ( $<12$ weight percent each) (Zosin and others, 2011).

In addition to the Kovdor deposit, baddeleyite has been recovered in the past as a byproduct of copper and phosphate (apatite) mining of the Palabora carbonatite complex in Limpopo Province, South Africa. Tailings from the main operation circuit were reprocessed by gravity separation to recover baddeleyite and uranium oxides. In 1990, approximately 15,000 metric tons of baddeleyite were recovered from 29 million metric tons of ore (Towner, 1992, p. 4). The mine waste and tailings produced from exploiting this complex have a different mineralogy and chemistry than those generated at Kovdor because of differences in the compositions of the ores. In addition to apatite, baddeleyite, magnetite and vermiculite, the Palabora ore also contains economic amounts of copper sulfides (primarily chalcopyrite and bornite) and uranium minerals (uraninite-thorite).

\section{Acid-Base Accounting}

Little information quantifying the acid-generating and acid-neutralizing potentials of mine waste from heavymineral sands and from the Kovdor carbonatite complex is available. One study in Australia examined the potential of heavy-mineral sands to generate acid at a specific deposit (Landers and Usher, 2012). This work revealed that potentially acid-generating material was found within the deposit owing to the presence of pyrite. Sulfur at this deposit is present almost entirely as sulfide and occurs in the organic-rich layers of overburden materials (at a median grade of 0.66 percent sulfur) and in the orebody (at a median grade of 1.10 percent sulfur). The maximum potential acidity (that is, the maximum amount of sulfuric acid that could be produced) was low to moderate, with median values of 20 and 34 kilograms of calcium carbonate per metric ton $\left(\mathrm{kg} \mathrm{CaCO}_{3} / \mathrm{t}\right)$ reported for organic-rich overburden and ore, respectively. The acid neutralizing capacity (that is, the amount of acid the sample can neutralize) was extremely low, and the paste $\mathrm{pH}$ (that is, the $\mathrm{pH}$ of water after it is mixed with a sample) values were highly acidic for ore and organic-rich overburden (Landers and Usher, 2012). Overall, much of the heavy-mineral sands ore material and some of the overburden have the potential to generate acid; the overburden that is not organic-rich is unlikely to generate acid. In general, heavy-mineral sands do not contain significant amounts of carbonates and offer little buffering capacity. Therefore, even trace amounts of sulfides can result in an acid-generating material. At the Green Cove Springs Mine in Florida, natural as well as reclamation pit soils were acidic (Daniels and others, 1992) and, at the Old Hickory Mine in Virginia, the subsurface material in the reclamation pits was generally acidic $(\mathrm{pH}<5.5)$ (Orndorff and others, 2005). At the Old Hickory Mine, the clay-rich layers within the waste piles were commonly strongly acidic and any neutral soil $\mathrm{pH}$ was at the surface because of the addition of lime to the piles.

In contrast to heavy-mineral sand deposits that commonly lack carbonate minerals, carbonatite deposits are carbonate rich. Pyrite, pyrrhotite, and several other sulfides that may be present in carbonatites have the potential to produce metal-rich acidic drainage but, in most cases, carbonates in the host rocks neutralize the acidity (Modreski and others, 1995). The Kovdor carbonatite deposit contains chalcopyrite, pyrite, and pyrrhotite but is dominated by calcite and dolomite (Petrov, 2004). Reshetnyak and others (2008) noted high concentrations of sulfate as well as high $\mathrm{pH}$ for groundwater draining from the Kovdor Mine site. The source of sulfate is likely from the oxidation of sulfides, which can produce acid, depending on the sulfide mineralogy; the high $\mathrm{pH}$ results from buffering during the dissolution of carbonates. 


\section{Human Health Concerns}

Zirconium and hafnium are likely not essential for human health and generally are considered elements of low toxicity to humans (Reimann and de Caritat, 1998). They can enter the human body by ingestion, inhalation, or dermal contact. Guidelines for drinking water and the consumption of aquatic organisms have not been established by the U.S. Environmental Protection Agency (EPA) for zirconium or hafnium and their toxicities have not been reviewed by the Agency for Toxic Substances and Disease Registry (ATSDR) or the World Health Organization (WHO). Also, the carcinogenic potentials of zirconium and hafnium have not been examined by the International Agency for Research on Cancer (IARC) (U.S. Environmental Protection Agency, 2012).

Human health concerns regarding exposure to zirconium and hafnium may be associated with industrial inhalation and dermal exposure. The EPA, in an attempt to define a toxicity value for soluble zirconium to be used at hazardous waste sites, reviewed relevant toxicity literature on human and animal studies from 1900 to 2012 and found that not enough information was available to derive a Provisional PeerReviewed Toxicity Value for Superfund (U.S. Environmental Protection Agency, 2012). The EPA has not conducted a comparable investigation on hafnium toxicity. The following is a summary of the findings reported by the EPA on zirconium (U.S. Environmental Protection Agency, 2012):

- Ingestion of large quantities of zirconium was shown to cause health issues in humans in one study, but this type of oral exposure is not likely to occur even in industrial settings.

- Some inhalation studies of workers producing or working with zirconium and hafnium metals and compounds have reported respiratory tract irritation, dermatitis, pulmonary fibrosis, and one case of an acute allergic hypersensitivity reaction that led to death.

- Several other industrial inhalation exposure studies on zirconium compounds found no abnormities or health issues.

- A few dermal exposure studies suggest zirconium may cause dermal lesions.

In addition to the EPA report (U.S. Environmental Protection Agency, 2012) and references therein, evidence that human exposure to zirconium compounds may cause inflammation of the skin was reported in Schaller (2004). The only toxicity symptoms reported from hafnium were for individual allergic sensitivity (Kabata-Pendias and Mukherjee, 2007).

Mining and dry separation processes conducted on heavy-mineral sands creates high amounts of airborne dust, which leads to inhalation and, to a lesser extent, dermal exposure. Elevated concentrations of zirconium have been detected in the lungs, blood, and urine of heavy-mineral sands miners (Patty and others, 1981). In the United States, the permissible exposure limits for zirconium and hafnium compounds in an 8-hour workday are 1.3 and $0.07 \mathrm{ppm}$ (5 and 0.5 milligrams per cubic meter), respectively (Occupational Safety and Health Administration, 2013). The radioactivity of the dust is also a concern during processing steps that concentrate radioactive minerals. For example, dry processing heavy-mineral sands to concentrate monazite increases radiation levels. Control measures, such as adequate ventilation and air filters, reduce the exposure levels to just the dust encountered during mining and milling operations.

\section{Ecological Health Concerns}

Because of the low solubility of zirconium and hafnium, ecological health concerns in the aquatic environment are minimal. Suter (1996) proposed values of between 982 and $54.9 \mathrm{ppb}$ zirconium as secondary acute and chronic toxicological benchmarks, respectively, for freshwater biota; hafnium was not considered. The benchmarks were established using fewer data than required to establish EPA aquatic water-quality criteria (Suter, 1996). For comparison to the benchmarks, mean concentrations of zirconium in stream waters worldwide are between 0.9 and $90 \mathrm{ppb}$ (Reimann and de Caritat, 1998). An estimated lowest chronic toxicity value for fish is $548 \mathrm{ppb}$ based on a lethal concentration for 50 percent $\left(\mathrm{LC}_{50}\right)$ of the test animals (Suter, 1996). Borgmann and others (2005) reported that the toxicity risk of hafnium to freshwater amphipods (Hyalella azteca) is low and comparable to that of zirconium. The $\mathrm{LC}_{50}$ in controlled laboratory tests was estimated to be greater than $1,000 \mathrm{ppb}$ for both zirconium and hafnium (Borgmann and others, 2005) values that are more than 10 times greater than the worldwide mean concentrations.

Similar to the aquatic environment, ecological health concerns from zirconium and hafnium in soils are minimal. Only a small proportion of zirconium in soil is taken up by plants, and it does not accumulate in the food chain. Also, the low mobility of zirconium within the plant organs is evidenced by its commonly higher concentrations in the roots than in the top vegetation (Kabata-Pendias and Mukherjee, 2007). Despite the low soil mobility and bioavailability of zirconium, Shahid and others (2013) and references therein reported some cases of reduced plant growth and modifications in enzyme activities owing to zirconium uptake by plants.

Although zirconium and hafnium are usually not of environmental concern from mining, other associated metals are potentially deleterious to the environment, especially if concentrated in mine waste or tailings. Tailings from some carbonatite mines in particular contain significant concentrations of thorium and uranium (Modreski and others, 1995) and other heavy metals. For example, waters draining tailings piles at the Kovdor Mine in Russia contain copper, manganese, 
and strontium in concentrations higher than local water quality guidelines (Zosin and others, 2011). Also, apatite, baddeleyite, and zircon from the Kovdor deposit have been shown to be enriched in thorium and uranium (Amelin and Zaitsev, 2002) and tailings containing these minerals have the potential to be radioactive. The final baddeleyite concentrate at the Kovdor Mine was reported to contain low radioactivity (59 becquerels per gram) (Petrov, 2004), suggesting that the tailings, likewise, are only minimally radioactive.

Another ecological concern specifically related to mine sites involves the failure of tailings dams. This hazard poses an ecological concern at heavy-mineral sand mines and igneous rock deposits. In 2010, a settling pond at the Moma heavy-mineral sands mine in Mozambique breached its retaining wall and released water, sand, and clay that flooded a nearby village, causing one fatality and extensive damage to property (Gambogi, 2012a). Also, the release of large amounts of mining waste into downstream waterways physically suffocates aquatic biota and releases metals into waters and sediments. No known tailings dam failure at a heavy-mineral sand mine has taken place in the United States.

\section{Mine Closure}

Heavy-mineral sand mining leads to increased erosion rates when improperly managed, disturbs the surrounding ecosystem, and alters the character of the land. Tailings and slimes are used as backfill or disposed of in large waste piles. Commonly, the topsoil initially removed at a site is stored during mining and either mixed with tailings and slimes or placed on top of waste piles; topsoil and other amendments, such as lime, fertilizers, and biosolids, added to the waste facilitate the return of vegetation. The disturbed mined lands can be successfully returned to local region agricultural levels when these sorts of reclamation practices are used based on results reported in Orndorff and others (2011) and Zimmerman and others (2008) from the Old Hickory Mine in Virginia. At the Green Cove Springs Mine in Florida, returning the land to pine forest involved rebuilding the landform with tailings, replacing topsoil, reestablishing the growth of the pines and ensuring surface stabilization from re-colonization of grasses (Brooks, 2000). In Australia, farmland in Western Australia was reclaimed for grazing by mixing clay slimes into the soils to improve their capacity to hold water and adsorb plant nutrients. Also in Australia, sand dunes mined in New South Wales and Queensland were reclaimed by reestablishing the original slope and landforms and performing surface stabilization and revegetation (Brooks, 2000). In general, many of the lands mined for heavy-mineral sands have been reclaimed to native conditions and returned to productive uses.
Closure plans for the current mining operation at the Kovdor complex will involve management of the large open pit as well as the extensive waste piles. Future plans for the mine, which is expected to continue operations until at least 2032 , include developing a deeper mine pit that will reach a depth of $900 \mathrm{~m}$ by expanding the current Zhelezny open pit operation that is $2.4 \mathrm{~km}$ long, $1.6 \mathrm{~km}$ wide, and $170 \mathrm{~m}$ deep without any significant enlargement of the pit rim (Ellenbecker, 2011). At mine closure, the large open pit is likely to be partially backfilled and flooded. Also, overburden, mine waste, and tailings piles that are presently several kilometers in length are expected to be expanded by future operations (Russian Academy of Sciences, 1999). Reclamation options for the waste piles include regrading, capping, adding soil amendments, revegetating, and possibly treating drainage and seepage waters.

\section{Problems and Future Research}

Because of the relative ubiquity of zircon in crustal rocks and the worldwide distribution of coastal environments with favorable geometries and conditions for placer formation (fig. V3), the outlook for zirconium and hafnium supply is generally favorable. In modern coastal environments, an integrated understanding of coastal morphology, sediment supply and distribution systems, geologic setting, and climate history is key for identifying and delineating heavy-mineral concentrations. In older coastal systems, relatively recent discoveries of significant heavy-mineral deposits in the Eucla basin of southern Australia (fig. V3; Hou and others, 2011) highlight the potential usefulness of a detailed reconstruction of major sea-level events combined with models for heavy-mineral concentration. The Gulf of Mexico Basin of the southern United States is a particularly prospective region with a long history of Cenozoic deposition and volumetrically significant Paleogene through Miocene coastal plain and shore zone facies deposits (Galloway and others, 2000). There is also potential for recoverable zirconium and hafnium resources in a wide variety of settings, including from tailings, where zircon is or was not the primary commodity of interest but may still be present at economic concentrations and is also relatively easy to extract.

Zirconium- and hafnium-bearing minerals have generally low solubility and reactivity; consequently, these elements do not pose significant threats to human health or the health of ecological systems. In heavy-mineral sand mining operations, the main environmental impact is landscape disruption by surface mining. It is common for modern mineral-sand mines to restore the landscape to pre-mining conditions. Thus, in many cases, the volume of mine waste and its impact on the landscape is generally only a temporary land-use issue. 


\section{References Cited}

Note: All Web links listed were active as of the access date but may no longer be available.

Ahrens, L.H, and Erlank, A.J., 1969, Hafnium, in Wedepohl, K.H., ed., Handbook of geochemistry, v. 2, pt. 5: Berlin, West Germany, Springer-Verlag.

Amelin, Yuri, and Zaitsev, A.N., 2002, Precise geochronology of phoscorites and carbonatites - The critical role of U-series disequilibrium in age interpretations: Geochimica et Cosmochimica Acta, v. 66, no. 13, p. 2399-2419. [Also available at http://dx.doi.org/10.1016/s0016-7037(02)00831-1.]

Arzamastsev, A.A., Glaznev, V.N., Raevsky, A.B., and Arzamastseva, L.V., 2000, Morphology and internal structure of the Kola alkaline intrusions, NE Fennoscandian Shield - 3D density modeling and geological implications: Journal of Asian Earth Sciences, v. 18, no. 2, p. 213-228. [Also available at http://dx.doi.org/10.1016/s1367-9120 (99)00052-8.]

Bailey, D.K., 1987, Mantle metasomatism-Perspective and prospect, in Fitton, J.G., and Upton, B.G.J., eds., Alkaline igneous rocks: Oxford, United Kingdom, Blackwell Scientific, Geological Society of London Special Publications Series, v. 30, p. 1-13. [Also available at http://dx.doi.org/10.1144/gsl.sp.1987.030.01.02.]

Bau, Michael, 1996, Controls on the fractionation of isovalent trace elements in magmatic and aqueous systemsEvidence from $\mathrm{Y} / \mathrm{Ho}, \mathrm{Zr} / \mathrm{Hf}$, and lanthanide tetrad effect: Contributions to Mineralogy and Petrology, v. 123, no. 3, p. 323-333. [Also available at http://dx.doi.org/10.1007/ s004100050159.]

Bedinger, G.M., 2014, Zirconium and hafnium [advance release], in Metals and minerals: U.S. Geological Survey Minerals Yearbook 2012, v. I, p. 85.1-85.8, accessed June 3, 2016, at https://minerals.usgs.gov/minerals/pubs/ commodity/zirconium/myb1-2012-zirco.pdf.

Bedinger, G.M., 2015a, Zirconium and hafnium [advance release], in Metals and minerals: U.S. Geological Survey Minerals Yearbook 2013, v. I, p. 85.1-85.7, accessed June 3, 2016, at https://minerals.usgs.gov/minerals/pubs/ commodity/zirconium/myb1-2013-zirco.pdf.

Bedinger, G.M., 2015b, Zirconium and hafnium: U.S. Geological Survey Mineral Commodity Summaries 2015, p. 188-189. [Also available at http://minerals.usgs.gov/minerals/pubs/ commodity/zirconium/mcs-2015-zirco.pdf.]

Bell, Keith, Dunworth, E.A., Bulakh, A.G., and Ivanikov, V.V., 1996, Alkaline rocks of the Turiy Peninsula, Russia, including type-locality turjaite and turjite-A review: Canadian Mineralogist, v. 34, pt. 2, p. 265-280. [Also available at http://rruff.info/doclib/cm/vol34/CM34_265.pdf.]
Bergman, S.C., 1987, Lamproites and other potassium-rich igneous rocks - A review of their occurrence, mineralogy and geochemistry, in Fitton, J.G., and Upton, B.G.J., eds., Alkaline igneous rocks: Oxford, United Kingdom, Blackwell Scientific, Geological Society of London Special Publications Series, v. 30, p. 103-190. [Also available at http://dx.doi.org/10.1144/gsl.sp.1987.030.01.08.]

Borgmann, Uwe, Couillard, Yves, Doyle, Patrick, and Dixon, D.G., 2005, Toxicity of sixty-three metals and metalloids to Hyalella azteca at two levels of water hardness: Environmental Toxicology and Chemistry, v. 24, no. 3, p. 641-652. [Also available at http://dx.doi.org/10.1897/04-177r.1.]

Brathwaite, R.L., and Christie, A.B., 2006, Review of shoreline placer ilmenite deposits in New Zealand, in Christie, A.B., and Brathwaite, R.L., eds., Geology and exploration of New Zealand mineral deposits: Australasian Institute of Mining and Metallurgy Monograph series, v. 25, p. 43-48.

British Geological Survey, 2012, Risk list 2012-An update to the supply risk index for elements or element groups that are of economic value: Keyworth, Nottingham, United Kingdom, British Geological Survey, 12 p., accessed June 19, 2013, at https://www.bgs.ac.uk/downloads/ start.cfm?id=2643.

Brooks, C.K., 1969, On the distribution of zirconium and hafnium in the Skaergaard intrusion, East Greenland: Geochimica et Cosmochimica Acta, v. 33, no. 3, p. 357-374. [Also available at http://dx.doi.org/10.1016/0016-7037 (69)90168-9.]

Brooks, C.K., 1970, The concentrations of zirconium and hafnium in some igneous and metamorphic rocks and minerals: Geochimica et Cosmochimica Acta, v. 34, no. 3, p. 411-416. [Also available at http://dx.doi.org/10.1016/ 0016-7037(70)90117-1.]

Brooks, D.R., 2000, Reclamation of lands disturbed by mining of heavy minerals, in Barnhisel, R.I., Darmondy, R.G., and Daniels, W.L., eds., Reclamation of drastically disturbed lands: Madison, Wis., American Society of Agronomy, Crop Science Society of America, Soil Science Society of America, Agronomy monograph 41, p. 725-754. [Also available at http://dx.doi.org/10.2134/agronmonogr41.c29.]

Buynevich, I.V., FitzGerald, D.M., and van Heteren, Sytze, 2004, Sedimentary records of intense storms in Holocene barrier sequences, Maine, USA: Marine Geology, v. 210, nos. 1-4, p. 135-148. [Also available at http://dx.doi.org/ 10.1016/j.margeo.2004.05.007.]

Carpenter, R.H., and Carpenter, S.F., 1991, Heavy mineral deposits in the upper coastal plain of North Carolina and Virginia: Economic Geology, v. 86, p. 1657-1671. [Also available at http://dx.doi.org/10.2113/gsecongeo.86.8.1657.]

Černý, P., and Siivola, J., 1980, The Tanco pegmatite at Bernic Lake, Manitoba, XII. Hafnian zircon: Canadian Mineralogist, v. 18, pt. 3, p. 313-321. 
Chakhmouradian, A.R., and Wall, Frances, 2012, Rare earth elements-Minerals, mines, magnets (and more): Elements, v. 8, no. 5, p. 333-340. [Also available at http://dx.doi.org/ 10.2113/gselements.8.5.333.]

Clarke, J.D.A., Gammon, P.R., Hou, B., and Gallagher, S.J., 2003, Middle to late Eocene stratigraphic nomenclature and deposition in the Eucla basin: Australian Journal of Earth Sciences, v. 50, no. 2, p. 231-248. [Also available at http://dx.doi.org/10.1046/j.1440-0952.2003.00995.x.]

Collins, E.D., Del Cul, G.D., Terekhov, D.S., and Emmanuel, N.V., 2011, Recycle of zirconium from used nuclear fuel claddingA major element of waste reduction: WM2011, 37th Annual Radioactive Waste Management Symposium, February 27March 3, 2011, Phoenix, Ariz., Proceedings, 6 p., accessed February 1, 2013, at http://www.wmsym.org/archives/2011/ papers/11336.pdf.

Condie, K.C., and Lo, H.H., 1971, Trace element geochemistry of the Louis Lake batholith of early Precambrian age, Wyoming: Geochimica et Cosmochimica Acta, v. 35, no. 11, p. 1099-1119. [Also available at http://dx.doi.org/ 10.1016/0016-7037(71)90028-7.]

Corfu, Fernando, Hanchar, J.M., Hoskin, P.W.O., and Kinny, Peter, 2003, Atlas of zircon textures, chap. 16 of Hanchar, J.M., and Hoskin, P.W.O., eds., Zircon: Washington, D.C., Mineralogical Society of America, Reviews in Mineralogy and Geochemistry Series, v. 53, p. 469-500. [Also available at http://dx.doi.org/10.2113/0530469.]

Correia Neves, J.M., Lopes Nunes, J.E., and Sahama, T.G., 1974, High hafnium members of the zircon-hafnon series from the granite pegmatites of Zambezia, Mozambique: Contributions to Mineralogy and Petrology, v. 48, no. 1, p. 73-80. [Also available at http://dx.doi.org/10.1007/bf00399111.]

Cox, D.P., 1992, Descriptive model of diamond pipesModel 12, in Cox, D.P., and Singer, D.A., eds., Mineral deposit models: U.S. Geological Survey Bulletin 1693, p. 54. [Also available at http://pubs.er.usgs.gov/publication/b1693.]

Cronin, T.M., Bybell, L.M., Poore, R.Z., Blackwelder, B.W., Liddicoat, J.C., and Hazel, J.E., 1984, Age and correlation of emerged Pliocene and Pleistocene deposits, U.S. Atlantic Coastal Plain: Palaeogeography, Palaeoclimatology, Palaeoecology, v. 47, nos. 1-2, p. 21-51. [Also available at http://dx.doi.org/10.1016/0031-0182(84)90079-8.]

Daniels, W.L., Genthner, M.H., and Hodges, R.L., 1992, Soil development in sandy tailings derived from mineral sands mining in Florida, in Achieving land use potential through reclamation-Proceedings of the 9th Annual Meeting of the American Society for Surface Mining and Reclamation, Duluth, Minn., June 14-18, 1992: Princeton, W.Va., American Society for Surface Mining and Reclamation, p. 37-47. [Also available at http:/www.asmr.us/Portals/0/Documents/ Conference-Proceedings/1992/0037-Daniels.pdf.]
Daniels, W.L., Orndorff, Z.W., and Schroeder, P.D., 2003, Chemical and physical properties of mineral sands mine soils in southeastern Virginia, in Barnhisel, R.I., ed., Working together for innovative reclamation-Proceedings of a Joint Conference of [the] 9th Billings Land Reclamation Symposium and American Society of Mining and Reclamation 20th Annual National Conference, Billings, Mont., June 3-6, 2003: Lexington, Ky., American Society of Mining and Reclamation, p. 209-228. [Also available at http:/www.asmr.us/Publications/Conference Proceedings 2003/0209-Daniels.pdf.]

David, K., Schiano, P., and Allegre, C.J., 2000, Assessment of the $\mathrm{Zr} / \mathrm{Hf}$ fractionation in oceanic basalts and continental materials during petrogenetic processes: Earth and Planetary Science Letters, v. 178, nos. 3-4, p. 285-301. [Also available at http://dx.doi.org/10.1016/s0012-821x(00)00088-1.]

Dawson, J.B., 1987, The kimberlite clan-Relationship with olivine and leucite lamproites, and inferences for uppermantle metasomatism, in Fitton, J.G., and Upton, B.G.J., eds., Alkaline igneous rocks: Oxford, United Kingdom, Blackwell Scientific, Geological Society of London Special Publications Series, v. 30, p. 95-102. [Also available at http://dx.doi.org/10.1144/gsl.sp.1987.030.01.07.]

Dickinson, W.R., 2008, Impact of differential zircon fertility of granitoid basement rocks in North America on age populations of detrital zircon and implications for granite petrogenesis: Earth and Planetary Science Letters, v. 275, nos. 1-2, p. 80-92. [Also available at http://dx.doi.org/10.1016/j.epsl.2008.08.003.]

Downes, Hilary, Balaganskaya, Elena, Beard, A.D., Liferovish, Ruslan, and Demaiffe, Daniel, 2005, Petrogenetic processes in the ultramafic, alkaline and carbonatitic magmatism in the Kola alkaline provinceA review: Lithos, v. 85, nos. 1-4, p. 48-75. [Also available at http://dx.doi.org/10.1016/j.lithos.2005.03.020.]

Dudkin, O.B., and Mitrofanov, F.P., 1994, Features of the Kola alkali province: Geochemistry International, v. 31, no. 3, p. 1-11.

Edgar, A.D., 1987, The genesis of alkaline magmas with emphasis on their source regions-Inferences from experimental studies, in Fitton, J.G., and Upton, B.G.J., eds., Alkaline igneous rocks: Oxford, United Kingdom, Blackwell Scientific, Geological Society of London Special Publications Series, v. 30, p. 29-52. [Also available at http://dx.doi.org/10.1144/gsl.sp.1987.030.01.04.]

Elko, N.A., and Davis, R.A., Jr., 2006, Morphologic evolution of similar barrier islands with different coastal management: Journal of Coastal Research, special issue, v. I, no. 39, p. $127-131$.

Ellenbecker, Scott, 2011, Russian producer prepares to go super-deep: Engineering \& Mining Journal, v. 212, December, p. 120-121, accessed February 12, 2013, at http://emj.epubxp.com/i/50645/121. 
Ellison, A.J., and Hess, P.C., 1986, Solution behavior of +4 cations in high silica melts-Petrologic and geochemical implications: Contributions to Mineralogy and Petrology, v. 94, no. 3, p. 343-351. [Also available at http://dx.doi.org/ 10.1007/BF00371443.]

Elsner, Harald, 2010, Assessment manual-Heavy minerals of economic importance: Hannover, Germany, Bundesanstalt für Geowissenschaften und Rohstoffe (BGR) [Federal Institute for Geosciences and Natural Resources], 218 p., accessed June 19, 2013, at http://www.bgr.bund.de/DE/Themen/ Min_rohstoffe/Downloads/heavy-minerals-economicimportance.pdf;jsessionid=1F6B0D5639695587638EFA19 F7DCDACA.1_cid297?_blob=publicationFile \&v=5.

Engel, A.E.J., Engel, C.G., and Havens, R.G., 1965, Chemical characteristics of oceanic basalts and the upper mantle: Geological Society of America Bulletin, v. 76, no. 7, p. 719-734. [Also available at http://dx.doi.org/10.1130/ 0016-7606(1965)76[719:ccooba]2.0.co;2.]

Fitton, J.G., 1987, The Cameroon line, West Africa-A comparison between oceanic and continental alkaline volcanism, in Fitton, J.G., and Upton, B.G.J., eds., Alkaline igneous rocks: Oxford, United Kingdom, Blackwell Scientific, Geological Society of London Special Publications Series, v. 30, p. 279-291.

Flohr, M.J.K., and Ross, Malcolm, 1990, Alkaline igneous rocks of Magnet Cove, Arkansas-Mineralogy and geochemistry of syenites: Lithos, v. 26, nos. 1-2, p. 67-98. [Also available at http://dx.doi.org/10.1016/ 0024-4937(90)90041-x.]

Force, E.R., 1991, Geology of titanium-mineral deposits: Geological Society of America Special Paper 259, 112 p. [Also available at http://dx.doi.org/10.1130/spe259-p1.]

Force, E.R., and Rich, F.J., 1989, Geologic evolution of Trail Ridge eolian heavy-mineral sand and underlying peat, northern Florida: U.S. Geological Survey Professional Paper 1499, 16 p. [Also available at http://pubs.er.usgs.gov/ publication/pp1499.]

Fujiyasu, Yoshimasa, Fahey, Martin, and Newson, Tim, 2000, Field investigation of evaporation from freshwater tailings: Journal of Geotechnical and Geoenvironmental Engineering, v. 126 , no. 6, p. 556-567. [Also available at http://dx.doi.org/ 10.1061/(asce)1090-0241(2000)126:6(556).]

Gaillardet, J., Viers, J., and Dupré, B., 2003, Trace elements in river waters, in Drever, J.I., ed., Surface and ground water, weathering and soils, v. 5 of Holland, H.D., and Turekian, K.K., eds., Treatise on geochemistry: Oxford, United Kingdom, Elsevier-Pergamon, p. 225-272. [Also available at http://dx.doi.org/10.1016/b0-08-043751-6/05165-3.]

Galloway, W.E., Ganey-Curry, P.E., Li, Xiang, and Buffler, R.T., 2000, Cenozoic depositional history of the Gulf of Mexico Basin: AAPG Bulletin, v. 84, no. 11, p. 1743-1774. [Also available at http://dx.doi.org/10.1306/8626c37f-173b-11d78645000102c1865d.]
Gambogi, Joseph, 2010, Zirconium and hafnium, in Metals and minerals: U.S. Geological Survey Minerals Yearbook 2007, v. I, p. 85.1-85.9. [Also available at http://minerals.usgs.gov/minerals/pubs/commodity/ zirconium/myb1-2007-zirco.pdf.]

Gambogi, Joseph, 2012a, Zirconium and hafnium, in Metals and minerals: U.S. Geological Survey Minerals Yearbook 2010, v. I, p. 85.1-85.8. [Also available at http://minerals.usgs.gov/minerals/pubs/commodity/ zirconium/myb1-2010-zirco.pdf.]

Gambogi, Joseph, 2012b, Zirconium and hafnium: U.S. Geological Survey Mineral Commodity Summaries 2012, p. 190-191. [Also available at https://minerals.usgs.gov/ minerals/pubs/commodity/zirconium/mcs-2012-zirco.pdf.]

Garnett, R.H.T., and Bassett, N.C., 2005, Placer deposits, in Economic Geology - One hundredth anniversary volume: Littleton, Colo., Society of Economic Geologists, p. 813-843, 1 CD-ROM.

Gill, J.B., 1981, Orogenic andesites and plate tectonics: New York, N.Y., Springer, Minerals and Rocks Series, v. 16, 390 p.

Govindaraju, K., 1994, 1994 compilation of working values and sample description for 383 geostandards: Geostandards Newsletter, v. 18, Issue Supplement S1, 158 p. [Also available at http://dx.doi.org/10.1046/ j.1365-2494.1998.53202081.x-i1.]

Graedel, T.E., Allwood, Julian, Birat, J.-P., Buchert, Matthias, Hagelüken, Christian, Reck, B.K., Sibley, S.F., and Sonnemann, Guido, 2011, What do we know about metal recycling rates?: Journal of Industrial Ecology, v. 15, no. 3, p. 355-366. [Also available at http://dx.doi.org/10.1111/j.1530-9290.2011.00342.x.]

Hails, J.R., and Hoyt, J.H., 1972, The nature and occurrence of heavy minerals in Pleistocene and Holocene sediments of the lower Georgia coastal plain: Journal of Sedimentary Petrology, v. 42, no. 3, p. 646-666. [Also available at http://dx.doi.org/10.1306/74d725ea-2b21-11d7$8648000102 \mathrm{c} 1865 \mathrm{~d}$.]

Hamilton, N.T.M., 1995, Controls on the global distribution of coastal titanium-zirconium placers: International Geology Review, v. 37, no. 9, p. 755-779. [Also available at http://dx.doi.org/10.1080/00206819509465426.]

Hanson, W.D., 1997, Heavy-mineral sands of the Tokio Formation in southwest Arkansas: Little Rock, Ark., Arkansas Geological Commission Information Circular, IC-34, 9 p.

Heaman, L.M., and LeCheminant, A.N., 1993, Paragenesis and $\mathrm{U}-\mathrm{Pb}$ systematics of baddeleyite $\left(\mathrm{ZrO}_{2}\right)$ : Chemical Geology, v. 110, nos. 1-4, p. 95-126. [Also available at http://dx.doi.org/10.1016/0009-2541(93)90249-i.] 
Heaman, L.M., Bowins, Robert, and Crocket, James, 1990, The chemical composition of igneous zircon suitesImplications for geochemical tracer studies: Geochimica et Cosmochimica Acta, v. 54, no. 6, p. 1597-1607. [Also available at http://dx.doi.org/10.1016/00167037(90)90394-z.]

Hoffman, A.W., 1997, Mantle geochemistry_The message from ocean volcanism: Nature, v. 385, no. 6613, p. 219-229. [Also available at http://dx.doi.org/10.1038/385219a0.]

Hoskin, P.W.O., and Schaltegger, Urs, 2003, The composition of zircon and igneous and metamorphic petrogenesis, chap. 2 of Hanchar, J.M., and Hoskin, P.W.O., eds., Zircon: Reviews in Mineralogy and Geochemistry, v. 53, p. 27-62. [Also available at http://dx.doi.org/10.2113/0530027.]

Hou, Baohong, Keeling, John, Reid, Anthony, Fairclough, Martin, Warland, Ian, Belousova, Elena, Frakes, Larry, and Hocking, Roger, 2011, Heavy mineral sands in the Eucla basin, southern Australia_-Deposition and province-scale prospectivity: Economic Geology, v. 106, p. 687-712. [Also available at http://dx.doi.org/10.2113/econgeo.106.4.687.]

Inman, D.L., and Nordstrom, C.E., 1971, On the tectonic and morphologic classification of coasts: Journal of Geology, v. 79, no. 1, p. 1-21. [Also available at http://dx.doi.org/ 10.1086/627583.]

Kabata-Pendias, Alina, and Mukherjee, A.B., 2007, Trace elements from soil to human: Berlin, Germany, SpringerVerlag, 550 p. [Also available at http://dx.doi.org/ 10.1007/978-3-540-32714-1.]

Kelemen, P.B., Johnson, K.T.M., Kinzler, R.J., and Irving, A.J., 1980, High-field-strength element depletions in arc basalts due to mantle-magma interaction: Nature, v. 345 , no. 6275 , p. 521-524. [Also available at http://dx.doi.org/10.1038/ 345521a0.]

Klemme, Stephan, and Meyer, Hans-Peter, 2003, Trace element partitioning between baddeleyite and carbonatite melt at high pressures and high temperatures: Chemical Geology, v. 199, nos. 3-4, p. 233-242. [Also available at http://dx.doi.org/10.1016/s0009-2541(03)00081-0.]

Kogarko, L.N., 1987, Alkaline rocks of the eastern part of the Baltic Shield (Kola Peninsula), in Fitton, J.G., and Upton, B.G.J., eds., Alkaline igneous rocks: Oxford, United Kingdom, Blackwell Scientific, Geological Society of London Special Publications Series, v. 30, p. 531-544. [Also available at http://dx.doi.org/10.1144/gsl.sp.1987.030.01.26.]

Kogarko, L.N., 1990, Ore-forming potential of alkaline magmas: Lithos, v. 26, nos. 1-2, p. 167-175. [Also available at http://dx.doi.org/10.1016/0024-4937(90)90046-4.]

Komar, P.D., and Wang, Chi, 1984, Processes of selective grain transport and the formation of placers on beaches: Journal of Geology, v. 92, no. 6, p. 637-655. [Also available at http://dx.doi.org/10.1086/628903.]
Kononov, M.E., Beloborodov, V.I., Nikitenko, N.G., and Zorina, T.A., 1992, Investigations of baddeleyite-forsterite products from the Kovdorsk mining-beneficiation combine: Refractories, v. 33, no. 3, p. 209-211. [Also available at http://dx.doi.org/10.1007/bf01283567.]

Kramm, U., Kogarko, L.N., Kononova, V.A., and Vartiainen, H., 1993, The Kola alkaline province of the CIS and FinlandPrecise Rb-Sr ages define 380-360 Ma age range for all magmatism: Lithos, v. 30, no. 1, p. 33-44. [Also available at http://dx.doi.org/10.1016/0024-4937(93)90004-v.]

Landers, Matt, and Usher, Brent, 2012, Acid metalliferous leaching of a mineral sands deposit-From field to laboratory, in McCullough, C.D., Lund, M.A., and Wyse, Lorraine, eds., International Mine Water Association Symposium 2012 - Mine Water and the Environment, Bunbury, Western Australia, Australia, 29 September4 October 2012, Proceedings: Red Hook, N.Y., Curran Associates, p. 215-221. [Also available at http://www.mwen.info/ docs/imwa_2012/IMWA2012_Landers_215.pdf.]

Leatherman, S.P., Williams, A.T., and Fisher, J.S., 1977, Overwash sedimentation associated with a large-scale northeaster: Marine Geology, v. 24, no. 2, p. 109-121. [Also available at http://dx.doi.org/10.1016/00253227(77)90004-4.]

Le Maitre, R.W., ed., with Streckeisen, A., Zanettin, B., Le Bas, M.J., Bonin, B., Bateman, P., Bellieni, G., Dudek, A., Efremova, S., Keller, J., Lameyre, J., Sabine, P.A., Schmid, R., Sørensen, H., and Woolley, A.R., 2002, Igneous rocks-A classification and glossary of terms - Recommendations of the International Union of Geological Sciences Subcommission on the Systematics of Igneous Rocks: New York, N.Y., Cambridge University Press, 236 p.

Levinson, A.A., and Borup, R.A., 1960, High hafnium zircon from Norway: American Mineralogist, v. 45, nos. 5-6, p. 562-565.

Loferski, P.J., 2013a, Zirconium and hafnium [advance release], in Metals and minerals: U.S. Geological Survey Minerals Yearbook 2011, v. I, p. 85.1-85.8. [Also available at http://minerals.usgs.gov/minerals/pubs/commodity/ zirconium/myb1-2011-zirco.pdf.]

Loferski, P.J., 2013b, Zirconium and hafnium: U.S. Geological Survey Mineral Commodity Summaries 2013, p. 190-191. [Also available at https://minerals.usgs.gov/minerals/pubs/ commodity/zirconium/mcs-2013-zirco.pdf.]

MacDonald, W.G., and Rozendaal, A., 1995, The Geelwal Karoo heavy mineral deposit-A modern day beach placer: Journal of African Earth Sciences, v. 21, no. 1, p. 187-200. [Also available at http://dx.doi.org/10.1016/0899-5362(95)00082-5.]

Mallik, T.K., Vasudevan, V., Aby Verghese, P., and Machado, Terry, 1987, The black sand placer deposits of Kerala Beach, southwest India: Marine Geology, v. 77, nos. 1-2, p. 129-150. [Also available at http://dx.doi.org/ 10.1016/0025-3227(87)90088-0.] 
Markewich, H.W., Pavich, M.J., and Buell, G.R., 1990, Contrasting soils and landscapes of the Piedmont and coastal plain, eastern United States: Geomorphology, v. 3, nos. 3-4, p. 417-447. [Also available at http://dx.doi.org/10.1016/0169-555x(90)90015-i.]

Marks, M.A.W., Hettmann, Kai, Schilling, Julian, Frost, B.R., and Markl, Gregor, 2011, The mineralogical diversity of alkaline igneous rocks - Critical factors for the transition from miaskitic to agpaitic phase assemblages: Journal of Petrology, v. 52, no. 3, p. 439-455. [Also available at http://dx.doi.org/10.1093/petrology/egq086.]

McGowran, Brian, Li, Qianyu, and Moss, Graham, 1997, The Cenozoic neritic record in southern Australia-The biogeohistorical framework, in James, N.P., and Clarke, J.A.D., eds., Cool-water carbonates: Tulsa, Okla., Society for Sedimentary Geology Special Publication Series, v. 56, p. 185-203. [Also available at http://dx.doi.org/10.2110/pec.97.56.0185.]

McKenzie, Dan, 1985, The extraction of magma from the crust and mantle: Earth and Planetary Science Letters, v. 74, no. 1, p. 81-91. [Also available at http://dx.doi.org/ 10.1016/0012-821x(85)90168-2.]

Menzies, Martin, 1987, Alkaline rocks and their inclusionsA window on the Earth's interior, in Fitton, J.G., and Upton, B.G.J., eds., Alkaline igneous rocks: Oxford, United Kingdom, Blackwell Scientific, Geological Society of London Special Publications Series, v. 30, p. 15-28. [Also available at http://dx.doi.org/10.1144/gsl.sp.1987.030.01.03.]

Minter, W.E.L., 2006, The sedimentary setting of Witwatersrand placer mineral deposits in an Archean atmosphere, in Kesler, S.E., and Ohmoto, Hiroshi, eds., Evolution of early Earth's atmosphere, hydrosphere, and biosphereConstraints from ore deposits: Boulder, Colo., Geological Society of America Memoir Series, v. 198, p. 105-119. [Also available at http://dx.doi.org/10.1130/2006.1198(06).]

Modreski, P.J., Armbrustmacher, T.J., and Hoover, D.B., 1995, Carbonatite deposits (Model 10; Singer, 1986a), chap. 6 of du Bray, E.A., ed., Preliminary compilation of descriptive geoenvironmental mineral deposit models: U.S. Geological Survey Open-File Report 95-831, p. 47-49. [Also available at http://pubs.usgs.gov/of/1995/ofr-95-0831/.]

Morton, A.C., and Hallsworth, C.R., 1999, Processes controlling the composition of heavy mineral assemblages in sandstones: Sedimentary Geology, v. 124, nos. 1-4, p. 3-29. [Also available at http://dx.doi.org/10.1016/ s0037-0738(98)00118-3.]

Murty, Ch.V.G.K., Gurung, R., Upadhyay, R., and Asokan, S., 2007, Tata Steel's Titania project-Challenges in slimes disposal, in Heavy minerals conference-Back to basics, 6th, Zulu Nyala, Hluhluwe, South Africa, September 10-14, 2007 : Johannesburg, South Africa, Southern African Institute of Mining and Metallurgy, Symposium Series, v. 48, p. 111-118. [Also available at http://www.saimm.co.za/Conferences/ HMC2007/111-118_Murty.pdf.]
Natural Earth, 2014, Small scale data: Natural Earth map dataset, scale 1:110,000,000, accessed June 23, 2014, at http://www.naturalearthdata.com.

Nickel, E.H., and Robinson, B.W., 1985, Kimrobinsonite, a new tantalum mineral from Western Australia, and its association with cesstibtantite: Canadian Mineralogist, v. 23 , pt. 4 , p. $573-576$.

Nielson, R.H., and Wilfling, Gerhard, 2002, Zirconium and zirconium compounds, in Ullmann's encyclopedia of industrial chemistry: Weinheim, Germany, Wiley-VCH Verlag GmbH \& Co., accessed January 10, 2013, at http://dx.doi.org/10.1002/14356007.a28_543.pub2.

Occupational Safety and Health Administration, 2013, Table Z-1-Limits for air contaminants-Occupational Safety and Health Standard number 1910.1000: U.S. Department of Labor, Occupational Safety and Health Administration, accessed February 15, 2013, at http://www.osha.gov/pls/oshaweb/owadisp.show_ document?p_table=standards\&p_id=9992.

Opdyke, N.D., Spangler, D.P., Smith, D.L., Jones, D.S., and Lindquist, R.C., 1984, Origin of the epeirogenic uplift of Pliocene-Pleistocene beach ridges in Florida and development of the Florida karst: Geology, v. 12, no. 4, p. 226-228. [Also available at http://dx.doi.org/10.1130/0091-7613(1984) 12\%3C226:ooteuo\%3E2.0.co;2.]

Orndorff, Z.W., Daniels, W.L., and Galbraith, J.M., 2005, Properties and classification of mineral sands mine soils in southeastern Virginia, in Barnhisel, R.I., ed., Proceedings of a joint conference of the American Society of Mining and Reclamation, 22d, Breckenridge, Colo., June 19-23, 2005: Breckenridge, Colo., American Society of Mining and Reclamation, p. 842-861. [Also available at http://asmr.us/ Publications/Conference\%20Proceedings/2005/0842Orndorff-VA.pdf.]

Orndorff, Z.W., Daniels, W.L., Meredith, K.R., Alley, M.M., and Wick, A.F., 2011, Effects of prime farmland soil reconstruction methods on post-mining productivity of mineral sands mine soils in Virginia, in Barnhisel, R.I., ed., Reclamation-Sciences leading to success, Proceedings of the 28th Annual Meeting of the American Society of Mining and Reclamation-Bismarck, North Dakota, June 11-16, 2011: Lexington, Ky., American Society of Mining and Reclamation, p. 504-518. [Also available at http://landrehab.org/UserFiles/DataItems/7A5A565056 4671794835553D/Orndorff\%20et\%20al.,\%202011\%20 ASMR\%20Effects\%20of\%20prime\%20farmland.pdf.]

Patty, F.A., Clayton, G.D., and Clayton, F.E., eds., 1981, Patty's industrial hygiene and toxicology, v. 2 (3d rev. ed.): New York, N.Y., John Wiley \& Sons, 1,420 p.

Pearce, J.A., and Norry, M.J., 1979, Petrogenetic implications of $\mathrm{Ti}, \mathrm{Zr}, \mathrm{Y}$, and $\mathrm{Nb}$ variations in volcanic rocks: Contributions to Mineralogy and Petrology, v. 69, no. 1, p. 33-47. [Also available at http://dx.doi.org/10.1007/bf00375192.] 
Perfit, M.R., Gust, D.A., Bence, A.E., Arculus, R.J., and Taylor, S.R., 1980, Chemical characteristics of islandarc basalts-Implications for mantle sources: Chemical Geology, v. 30, no. 3, p. 227-256. [Also available at http://dx.doi.org/10.1016/0009-2541(80)90107-2.]

Peterson, C.D., Gleeson, G.W., and Wetzel, Nick, 1987, Stratigraphic development, mineral resources and preservation of marine placers from Pleistocene terraces in southern Oregon, U.S.A.: Sedimentary Geology, v. 53, nos. 3-4, p. 203-229. [Also available at http://dx.doi.org/ 10.1016/0037-0738(87)90035-2.]

Peterson, C.D., Komar, P.D., and Scheidegger, K.F., 1986, Distribution, geometry, and origin of heavy mineral placer deposits on Oregon beaches: Journal of Sedimentary Research, v. 56, no. 1, p. 67-77. [Also available at http://dx.doi.org/10.1306/212f8887-2b24-11d7$8648000102 \mathrm{c} 1865 \mathrm{~d}$.]

Petrov, S.V., 2004, Economic deposits associated with the alkaline and ultrabasic complexes of the Kola Peninsula, in Wall, F., and Zaitsev, A.N., eds., Phoscorites and carbonatites from mantle to mine- The key example of the Kola alkaline province: London, United Kingdom, Mineralogical Society of Great Britain and Ireland, The Mineralogical Society Series, v. 10, p. 469-490.

Pirkle, E.C., Pirkle, F.L., Pirkle, W.A., and Stayert, P.R., 1984, The Yulee heavy mineral sand deposits of northeastern Florida: Economic Geology, v. 79, p. 725-737. [Also available at http://dx.doi.org/10.2113/gsecongeo.79.4.725.]

Pirkle, E.C., Pirkle, W.A., and Yoho, W.H., 1974, The Green Cove Springs and Boulougne heavy-mineral sand deposits of Florida: Economic Geology, v. 69, p. 1129-1137. [Also available at http://dx.doi.org/10.2113/gsecongeo.69.7.1129.]

Pirkle, F.L., Pirkle, W.A., and Pirkle, E.C., 2007, Heavymineral sands of the Atlantic and Gulf Coastal Plains, USA, chap. 45 of Mange, M.A., and Wright, D.T., eds., Heavy minerals in use: Boston, Mass., Elsevier, Developments in Sedimentology Series, v. 58, p. 1145-1232. [Also available at http://dx.doi.org/10.1016/s0070-4571(07)58045-3.]

Premaratne, W.A.P.J., and Rowson, N.A., 2003, The processing of beach sand from Sri Lanka for the recovery of titanium using magnetic separation: Physical Separation in Science and Engineering, v. 12, no. 1, p. 13-22. [Also available at http://dx.doi.org/10.1080/1478647031000101232.]

Puffer, J.H., and Cousminer, H.L., 1982, Factors controlling the accumulation of titanium-iron oxide-rich sands in the Cohansey Formation, Lakehurst area, New Jersey: Economic Geology, v. 77, p. 379-391. [Also available at http://dx.doi.org/10.2113/gsecongeo.77.2.379.]

Pupin, J.P., 1980, Zircon and granite petrology: Contributions to Mineralogy and Petrology, v. 73, no. 3, p. 207-220. [Also available at http://dx.doi.org/10.1007/bf00381441.]
Reimann, Clemens, and de Caritat, Patrice, 1998, Chemical elements in the environment-Factsheets for the geochemist and environmental scientist: Berlin, Germany, SpringerVerlag, $398 \mathrm{p}$.

Reinson, G.E., 1979, Facies models 14. Barrier island systems: Geoscience Canada, v. 6, no. 2, p. 51-68. [Also available at https://journals.lib.unb.ca/index.php/GC/article/ view/3154/3671.]

Reshetnyak, Serguei, Melikhova, Galina, Fedotova, Yulia, and Melikhov, Mikhail, 2008, Problems of deep open pits closure in the Kola Peninsula, in Rapantova, Nada, and Hrkal, Zybnek, eds., Mine Water and the EnvironmentProceedings of the 10th IMWA Congress 2008, Karlsbad, Czech Republic, June 2-5, 2008: Wendelstein, Germany, International Mine Water Association, p. 171-174. [Also available at https://www.imwa.info/docs/imwa_2008/ IMWA2008_166_Reshetnyak.pdf.]

Rodionov, N.V., Belyatsky, B.V., Antonov, A.V., Kapitonov, I.N., and Sergeev, S.A., 2012, Comparative in-situ U-Th-Pb geochronology and trace element composition of baddeleyite and low-U zircon from carbonatites of the Paleozoic Kovdor alkaline-ultramafic complex, Kola Peninsula, Russia: Gondwana Research, v. 21, no. 4, p. 728-744. [Also available at http://dx.doi.org/10.1016/ j.gr.2011.10.005.]

Roy, P.S., 1999, Heavy mineral beach placers in southeastern Australia-Their nature and genesis: Economic Geology, v. 94, p. 567-588. [Also available at http://dx.doi.org/ 10.2113/gsecongeo.94.4.567.]

Roy, P.S., Cowell, P.J., Ferland, M.A., and Thom, B.G., 1994, Wave-dominated coasts, chap. 4 of Carter, R.W.G., and Woodroffe, C.D., eds., Coastal evolution-Late Quaternary shoreline morphodynamics: New York, N.Y., Cambridge University Press, p. 121-186.

Roy, P.S., Whitehouse, John, Cowell, P.J., and Oakes, Geoff, 2000, Mineral sands occurrences in the Murray basin, southeastern Australia: Economic Geology, v. 95, p. 1107-1128. [Also available at http://dx.doi.org/10.2113/ gsecongeo.95.5.1107.]

Rubatto, Daniela, and Hermann, Jörg, 2003, Zircon formation during fluid circulation in eclogites (Monviso, Western Alps)-Implications for $\mathrm{Zr}$ and $\mathrm{Hf}$ budget in subduction zones: Geochimica et Cosmochimica Acta, v. 67, no. 12, p. 2173-2187. [Also available at http://dx.doi.org/10.1016/ s0016-7037(02)01321-2.]

Rubatto, Daniela, Gebauer, Dieter, and Compagnoni, Roberto, 1999, Dating of eclogite-facies zircons - The age of Alpine metamorphism in the Sesia-Lanzo zone (Western Alps): Earth and Planetary Science Letters, v. 167, nos. 3-4, p. 141-158. [Also available at http://dx.doi.org/10.1016/ s0012-821x(99)00031-x.] 
Russian Academy of Sciences, 1999, Кадастр отходов горнометаллургического производства [Inventory of waste mining and metallurgical production]: Государственный комитет по охране окружающей среды Мурманской области, Кольский научный центр Горный институт [State Committee for Environmental Protection of the Murmansk Region, Kola Science Center of the Institute of Mines, RAS, accessed February 21, 2013, at http://www.murman.ru/ecology/cadastre/.

Saxena, S.K., 1966, Evolution of zircons in sedimentary and metamorphic rocks: Sedimentology, v. 6, no. 1, p. 1-33. [Also available at http://dx.doi.org/10.1111/ j.1365-3091.1966.tb01568.x.]

Schaller, K.-H., 2004, Zirconium, chap. 30 of Merian, E., Anke, M., Ihnat, M., and Stoeppler, M., eds., Elements and their compounds in the environment ( $2 \mathrm{~d}$ ed.): Weinheim, Germany, Wiley-VCH Verlag GmbH \& Co., p. 1241-1247. [Also available at http://dx.doi.org/ 10.1002/9783527619634.ch51.]

Schaltegger, U., Fanning, C.M., Günther, D., Maurin, J.C., Schulmann, K., and Gebauer, D., 1999, Growth, annealing and recrystallization of zircon and preservation of monazite in high-grade metamorphism - Conventional and in-situ $\mathrm{U}-\mathrm{Pb}$ isotope, cathodoluminescence and microchemical evidence: Contributions to Mineralogy and Petrology, v. 134, nos. 2-3, p. 186-201. [Also available at http://dx.doi.org/10.1007/s004100050478.]

Scharer, Urs, Corfu, Fernando, and Demaiffe, Daniel, 1997, $\mathrm{U}-\mathrm{Pb}$ and $\mathrm{Lu}-\mathrm{Hf}$ isotopes in baddeleyite and zircon megacrysts from the Mbuji-Mayi kimberlite - Constraints on the subcontinental mantle: Chemical Geology, v. 143, nos. 1-2, p. 1-16. [Also available at http://dx.doi.org/10.1016/ s0009-2541(97)00094-6.]

Shacklette, H.T., and Boerngen, J.G., 1984, Element concentrations in soils and other surficial materials of the conterminous United States: U.S. Geological Survey Professional Paper 1270, 105 p. [Also available at http://pubs.usgs.gov/pp/1270/.]

Shahid, Muhammad, Ferrand, Emmanuel, Schreck, Eva, and Dumat, Camille, 2013, Behavior and impact of zirconium in the soil-plant system-Plant uptake and phytotoxicity, chap. 2 of Whitacre, D.M., ed., Reviews of environmental contamination and toxicology: Springer, New York, N.Y., Reviews of Environmental Toxicology Series, v. 221, p. 107-127. [Also available at http://dx.doi.org/10.1007/ 978-1-4614-4448-0_2.]

Sindern, S., Zaitsev, A.N., Demény, A., Bell, K., Chakmouradian, A.R., Kramm, U., Moutte, J., and Rukhlov, A.S., 2004, Mineralogy and geochemistry of silicate dyke rocks associated with carbonatites from the Khibina complex (Kola, Russia)-Isotope constraints on genesis and small-scale mantle sources: Mineralogy and Petrology, v. 80, nos. 3-4, p. 215-239. [Also available at http://dx.doi.org/10.1007/s00710-003-0016-2.]
Singer, D.A., 1992, Descriptive model of carbonatite deposits,-Model 10, in Cox, D.P., and Singer, D.A., eds., Mineral deposit models: U.S. Geological Survey Bulletin 1693, p. 51. [Also available at https://pubs.er.usgs.gov/ publication/b1693.]

Slingerland, Rudy, and Smith, N.D., 1986, Occurrence and formation of water-laid placers: Annual Reviews of Earth and Planetary Sciences, v. 14, p. 113-147. [Also available at http://dx.doi.org/10.1146/annurev.earth.14.1.113.]

Söderlund, Ulf, and Johansson, Leif, 2002, A simple way to extract baddeleyite $\left(\mathrm{ZrO}_{2}\right)$ : Geochemistry, Geophysics, Geosystems, v. 3, no. 2, 7 p. [Also available at http://dx.doi.org/10.1029/2001GC000212.]

Sørenson, Henning, 1997, The agpaitic rocks-An overview: Mineralogical Magazine, v. 61, no. 407, p. 485-498.

Speer, J.A., and Cooper, B.J., 1982, Crystal structure of synthetic hafnon, $\mathrm{HfSiO}_{4}$, comparison with zircon and the actinide orthosilicates: American Mineralogist, v. 67, nos. 7-8, p. 804-808.

Suter, G.W., II, 1996, Toxicological benchmarks for screening contaminants of potential concern for effects on freshwater biota: Environmental Toxicology and Chemistry, v. 15, no. 7, p. 1232-1241. [Also available at http://dx.doi.org/ 10.1002/etc.5620150731.]

Sutherland, D.G., 1985, Geomorphological controls on the distribution of placer deposits: Journal of the Geological Society, v. 142, no. 5, p. 727-737. [Also available at http://dx.doi.org/10.1144/gsjgs.142.5.0727.]

Taylor, S.R., and McLennan, S.M., 1995, The geochemical evolution of the continental crust: Reviews of Geophysics, v. 33, no. 2, p. 241-265. [Also available at http://dx.doi.org/ 10.1029/95rg00262.]

Thompson, R.N., Morrison, M.A., Hendry, G.L., Parry, S.J., Simpson, P.R., Hutchison, R., and O'Hara, M.J., 1984, An assessment of the relative roles of crust and mantle in magma genesis - An elemental approach [and discussion]: Philosophical Transactions of the Royal Society of London, Series A, v. 310, no. 1514, p. 549-590. [Also available at http://dx.doi.org/10.1098/rsta.1984.0008.]

Towner, R.R., 1992, International Strategic Minerals Inventory summary report-Zirconium: U.S. Geological Survey Circular 930-L, 47 p. [Also available http://pubs.er.usgs.gov/ publication/cir930L.]

U.S. Environmental Protection Agency, 2012, Provisional peer-reviewed toxicity values for soluble zirconium compounds: U.S. Environmental Protection Agency, Chemical Assessment Summary, CASRN 7440-67-7, accessed February 21, 2013, at http://hhpprtv.ornl.gov/ issue_papers/Zirconium.pdf. 
U.S. Geological Survey, 1996, Global 30 arc-second elevation (GTOPO30): Reston, Va., U.S. Geological Survey dataset (digital elevation model), accessed June 23, 2014, at https://lta.cr.usgs.gov/GTOPO30.

U.S. Geological Survey, 2006-9, Metals and minerals: U.S. Geological Survey Minerals Yearbook 2004-2006, v. I, variously paged. [Also available at http://minerals.usgs.gov/ minerals/pubs/myb.html.]

U.S. Geological Survey, 2010-13, Metals and minerals: U.S. Geological Survey Minerals Yearbook 2008-2011, v. I, variously paged. [Also available at http://minerals.usgs.gov/ minerals/pubs/myb.html.]

U.S. Geological Survey, 2014, Zirconium mineral concentrates statistics [through 2014; last modified January 28, 2016], in Kelly, T.D., and Matos, G.R., comps., Historical statistics for mineral and material commodities in the United States (2014 version): U.S. Geological Survey Data Series 140, accessed March 4, 2017, at http://minerals.usgs.gov/ minerals/pubs/historical-statistics/.

Verhulst, A., Balaganskaya, E., Kirnarsky, Y., and Demaiffe, D., 2000, Petrological and geochemical (trace elements and Sr-Nd isotopes) characteristics of the Paleozoic Kovdor ultramafic, alkaline and carbonatite intrusion (Kola Peninsula, NW Russia): Lithos, v. 51, nos. 1-2, p. 1-25. [Also available at http://dx.doi.org/ 10.1016/s0024-4937(99)00072-9.]

Viers, Jérôme, Dupré, Bernard, and Gaillardet, Jérôme, 2009, Chemical composition of suspended sediments in world rivers-New insights from a new database: Science of the Total Environment, v. 407, no. 2, p. 853-868. [Also available at http://dx.doi.org/10.1016/j.scitotenv.2008.09.053.]

von Knorring, O., and Hornung, G., 1961, Hafnian zircons: Nature, v. 190, no. 4781, p. 1098-1099. [Also available at http://dx.doi.org/10.1038/1901098a0.]

Wager, L.R., and Mitchell, R.L., 1951, The distribution of trace elements during strong fractionation of basic magma-A further study of the Skaergaard intrusion, East Greenland: Geochimica et Cosmochimica Acta, v. 1, no. 3, p. 129-208. [Also available at http://dx.doi.org/10.1016/0016-7037 (51)90016-6.]
Wang, R.C., Fontan, Francois, Xu, Shijin, Chen, Xiaoming, and Monchoux, Pierre, 1996, Hafnian zircon from the apical part of the Suzhou granite, China: Canadian Mineralogist, v. 34, pt. 5, p. 1001-1010.

Watson, E.B., and Harrison, T.M., 1984, Accessory minerals and the geochemical evolution of crustal magmatic systems - A summary and prospectus of experimental approaches: Physics of the Earth and Planetary Interiors, v. 35, nos. 1-3, p. 19-30. [Also available at http://dx.doi.org/ 10.1016/0031-9201(84)90031-1.]

Weaver, B.L., Wood, D.A., Tarney, John, and Joron, J.L., 1987, Geochemistry of ocean island basalts from the South Atlantic-Ascension, Bouvet, St. Helena, Gough and Tristan da Cunha, in Fitton, J.G., and Upton, B.G.J., eds., Alkaline igneous rocks: Oxford, United Kingdom, Blackwell Scientific, Geological Society of London Special Publications Series, v. 30, p. 253-267. [Also available at http://dx.doi.org/10.1144/gsl.sp.1987.030.01.11.]

Winker, C.D., and Howard, J.D., 1977, Correlation of tectonically deformed shorelines on the southern Atlantic Coastal Plain: Geology, v. 5, no. 2, p. 123-127. [Also available at http://dx.doi.org/10.1130/0091-7613(1977)5\%3C123: cotdso $\% 3 \mathrm{E} 2.0 . \operatorname{co} ; 2$.

Zimmerman, Clint, Stilson, Chuck, and Daniels, W.L., 2008, Reclamation of mineral sands mine and topsoil replacement study, in Proceedings of the 25th Annual Meeting of the American Society of Mining and Reclamation and 10th meeting of the IALR, Richmond, VA, June 14-19, 2008 : Lexington, Ky., American Society of Mining and Reclamation, p. 1429-1444. [Also available at http://landrehab.org/ UserFiles/DataItems/61326B4E366357773754493D/ Zimmerman\%20et\%20al.,\%202008\%20ASMR\%20 Reclamation\%20of\%20Mineral-VA.pdf.]

Zosin, A.P., Priimak, T.I., Masloboev, V.A., Sulimenko, L.P., and Mingaleva, T.A., 2011, Variation in wastewater composition in the water use system of Kovdorskii mining-and-processing integrated works: Water Resources, v. 38, no. 1, p. 113-123. [Also available at http://dx.doi.org/10.1134/s0097807810061065.] 
For more information concerning this report, please contact:

Mineral Resources Program Coordinator

U.S. Geological Survey

913 National Center

Reston, VA 20192

Telephone: 703-648-6100

Fax: 703-648-6057

Email:minerals@usgs.gov

Home page: https://minerals.usgs.gov

Prepared by the USGS Science Publishing Network Reston Publishing Service Center

Edited by J.C. Ishee and Stokely J. Klasovsky

Illustrations by Caryl J. Wipperfurth

Layout by Caryl J. Wipperfurth and Cathy Y. Knutson

Posting by Angela E. Hall 
